\title{
ARTICLE
}

\section{MOVING BEYOND THE "IMMUTABILITY DEBATE" IN THE FIGHT FOR EQUALITY AFTER PROPOSITION 8}

\author{
M.K.B. DARMER ${ }^{\star}$ \\ TIFFANY CHANG**
}

I. Introduction................................... 2

II. LGBT Rights in the United States Supreme Court ....... 11

III. Marriage Equality in the States .................. 23

IV. Proposition 8 and the Peculiar Vulnerability of LGBTs.... 34

V. Moving Beyond Proposition $8 \ldots \ldots \ldots \ldots \ldots \ldots \ldots . . \ldots$

VI. Conclusion ................................... 44

"All men are created equal. No matter how hard you try, you can never erase those words."1

* Professor of Law, Chapman University School of Law. A.B., Princeton University; J.D., Columbia University School of Law. Founding board member and Legal Chair of the Orange County Equality Coalition (OCEC), a grass-roots organization formed after the passage of Proposition 8 in California. The author thanks Chapman University School of Law for a research stipend in support of this Article.

* Chapman University School of Law, Candidate for Juris Doctor 2010. OCEC Board Member. This Article draws on arguments made in an amicus brief filed by these authors and others in support of the prior petitions to invalidate Proposition 8. The authors thank Ronald Steiner and other colleagues who assisted with the amicus brief and our OCEC friends for sharing their stories. They also express appreciation to the editors of The Scholar: St. Mary's Law Review on Minority Issues.

1. Randy Shilts, The Mayor of Castro Street: The Life and Times of Harvey MiLk 225 (St. Martin's Griffin 2008) (1982) (quoting Harvey Milk, a gay rights activist and the first openly gay politician to be elected to public office in California in 1977). 


\section{INTRODUCTION}

Questions about whether sexual orientation is "immutable" have delayed the attainment of full equality for sexual orientation minorities. ${ }^{3}$ Those opposed to marriage equality, for example, have sought to draw distinctions between racial or ethnic minorities and sexual orientation minorities by arguing that only the former groups have "immutable" traits. ${ }^{4}$ This Article does not wade into the "immutability" debate, but instead

2. See Frontiero v. Richardson, 411 U.S. 677, 686 (1973) (Brennan, J., plurality opinion) (describing an immutable characteristic as a "characteristic determined solely by the accident of birth"). Webster's Dictionary defines "immutable" as "unchangeable." WEBSTER's Deluxe Unabridged Dictionary 910 (2d ed. 1983).

3. See Diane S. Meier, Note, Gender Trouble in the Law: Arguments Against the Use of Status/Conduct Binaries in Sexual Orientation Law, 15 W ASH. \& LEE J. Civ. RTs. \& Soc. Just. 147, 163 (2008) ("In terms of sex, gender, and sexual orientation, courts tie up notions of immutability with sex and gender performance and notions of mutability with sexual orientation. Notions of immutability and mutability provide a jurisprudential justification for withholding protection of sexual orientation and protecting sex and gender."); cf. id. at 185 ("[The] decision to characterize sexual orientation as mutable or immutable becomes objectively incoherent" when conduct is contrasted with orientation (emphasis in original)); Jo Becker, The Road to Championing Same-Sex Marriage, N.Y. Times, Aug. 19, 2009, at A14, available at 2009 WLNR 16127520 (noting that Ted Olson, in a federal marriage lawsuit, "dismisses" the contention that California's marriage ban is justified by a state interest in encouraging relationships that lead to procreation). "If sexual orientation is not a choice-and Mr. Olson argues that it is not-then the ban is not going to encourage his clients to enter into heterosexual, child-producing marriages, he insists." Id. The fact that the defenders of marriage bans rely on "encouraging procreation" as a justification for supporting marriage bans is, in our view, a species of an argument from immutability because it suggests that if marriage for same-sex couples is not an option, same-sex couples might opt to abandon same-sex partners in favor of opposite-sex partners, an argument that is ultimately grounded on the notion of "choice." As developed further in Part $V$ of this Article, our view is that sexual orientation is so integral to the person that for the state to seek to force or even encourage a "change" is inconsistent with the respect due to sexual orientation minorities.

4. See, e.g., Varnum v. Brien, 763 N.W.2d 862, 892 (Iowa 2009) (noting the local government's argument that plaintiffs, six same-sex couples, "could not prove, as a matter of fact, that sexuality is immutable"). The court found, however, that "[s]exual orientation is not the type of human trait that allows courts to relax their standard of review because the barrier is temporary or susceptible to self-help." Id. at 893. As Professor Janet Halley has pointed out, "anti-gay constructivists say that being gay, lesbian, or bisexual is a choice, and that for that reason forms a proper target for a majority that thinks these ways of being are morally bad and seeks to deter people from adopting them." Janet E. Halley, Sexual Orientation and the Politics of Biology: A Critique of the Argument from Immutability, 46 Stan. L. Rev. 503, 517 (1994) (noting former Vice President Dan Quayle's articulation of this viewpoint during the 1992 presidential campaign, when he stated: "My viewpoint is that it's more of a choice than a biological situation. . . . I think it is a wrong choice." (footnote omitted)). 
asserts that the immutability question is the wrong one to ask. ${ }^{5}$ Gender itself is not ultimately an "immutable" trait, ${ }^{6}$ and yet few would deny that discrimination based on gender is not only wrong, but also a violation of equal protection norms. ${ }^{7}$

The California Supreme Court's decision in In re Marriage Cases (Marriage Cases) provides the framework for moving beyond "immutability" questions to provide expanded protections to sexual orientation minorities. ${ }^{8}$ In that landmark decision, the court not only held that marriage is a

5. See Janet E. Halley, Sexual Orientation and the Politics of Biology: A Critique of the Argument from Immutability, 46 STAN. L. REv. 503, 506 (1994) (arguing that the "pro-gay legal arguments from biological causation should be abandoned"). Nevertheless, more than ten years later, arguments regarding immutability abound in the political arena and continue to inform judicial analysis of the issue. See, e.g., Varnum, 763 N.W.2d at 892 (discussing the immutability argument).

6. See Varnum, 763 N.W.2d at 893 (citing Iowa CoDE $§ 144.23$ (2008)) (referencing an Iowa statute that permits one to obtain a new birth certificate reflecting a gender reassignment).

7. See United States v. Virginia (VMI), 518 U.S. 515, 534 (1996) (finding that the Virginia Military Institute's male-only admissions policy did not serve an "exceedingly persuasive justification," as admitting women would not diminish the school's stature). The Court noted:

"Inherent differences" between men and women, we have come to appreciate, remain cause for celebration, but not for denigration of the members of either sex or for artificial constraints on an individual's opportunity. Sex classifications may be used to compensate women "for particular economic disabilities [they have] suffered" to "promot[e] equal employment opportunity," to advance full development of the talent and capacities of our Nation's people. But such classifications may not be used, as they once were, to create or perpetuate the legal, social, and economic inferiority of women.

Id. at 533-34 (citations omitted).

8. In re Marriage Cases, 183 P.3d 384, 442 (Cal. 2008) (overturning the court of appeals, which analyzed the case under the rational basis test after noting that questions existed regarding whether or not sexual orientation was "immutable"), superseded in part by constitutional amendment, CAL. Const. art. I, § 7.5, as recognized in Strauss v. Horton, 207 P.3d 48 (Cal. 2009). The California Supreme Court held that "immutability is not invariably required in order for a characteristic to be considered a suspect classification for equal protection purposes." Id. The court also noted that:

[O]ur decisions make clear that the most important factors in deciding whether a characteristic should be considered a constitutionally suspect basis for classification are whether the class of persons who exhibit a certain characteristic historically has been subjected to invidious and prejudicial treatment, and whether society now recognizes that the characteristic in question generally bears no relationship to the individual's ability to perform or contribute to society.

Id. at 443 . The Marriage Cases decision was superseded only in part by constitutional amendment, following passage of Proposition 8 , a voter initiative defining marriage as solely between one man and one woman. Because neither Proposition 8 nor the 2009 California Supreme Court decision recognizing its validity address the court's holding in the Marriage Cases that discrimination based on sexual orientation is subject to heightened 
fundamental right, ${ }^{9}$ but also that sexual orientation is a suspect classification for equal protection purposes under the California constitution. ${ }^{10}$ The court did not find it necessary to declare sexual orientation "immutable" in reaching that holding. ${ }^{11}$ Rather, it found, critically, that sexual orientation is so "integral" to the person that one should not have to change it to avoid discrimination. ${ }^{12}$

Of course, Proposition 8 partially undid the court's holding by amending the state constitution to provide that "only marriage between a man and a woman is valid or recognized in California." 13 On November 4,

scrutiny, we argue that the supersession was only partial. See also Richard Salas, In Re Marriage Cases: The Fundamental Right to Marry and Equal Protection Under the California Constitution and the Effects of Proposition 8, 36 HAstings ConsT. L.Q. 545, 560 (2009) ("Of overwhelming importance is something that Proposition 8 does not change: sexual orientation is now a suspect classification under . . California's equal protection clause triggering strict scrutiny review of any statute that is classified on this basis." (footnote omitted)).

9. In re Marriage Cases, 183 P.3d at 419 (stating that "the right to marry is a fundamental right whose protection is guaranteed to all persons by the California [c]onstitution").

10. Id. at 444. In the court's words:

Because sexual orientation, like gender, race, or religion, is a characteristic that frequently has been the basis for biased and improperly stereotypical treatment and that generally bears no relation to an individual's ability to perform or contribute to society, it is appropriate for courts to evaluate with great care and with considerable skepticism any statute that embodies such a classification. Id.

11. See $i d$. at 443 (declining to define sexual orientation as an immutable trait). Instead, the court determined that sexual orientation is a suspect classification because, historically, people have faced prejudice for sexual orientation. Id.

12. Id. at 442 (citation omitted) (comparing sexual orientation with religion and alienage, both examples of traits that are changeable, yet trigger strict scrutiny as a suspect classification). The court used these examples to explain why immutability is not required for suspect classification and emphasized that, because sexual orientation is so fundamental to a person's identity, he or she should not feel required to change it. See id.

13. California Secretary of State, Voter Guide: Text of Proposed Laws 128 (2008), http://voterguide.sos.ca.gov/past/2008/general/text-proposed-laws/text-of-proposedlaws.pdf. The Voter Guide provides:

This initiative measure is submitted to the people in accordance with the provisions of Article II, Section 8 , of the California Constitution.

This initiative measure expressly amends the California Constitution by adding a section thereto; therefore, new provisions proposed to be added are printed in italic type to indicate that they are new.

SECTION 1: Title

This measure shall be known and may be cited as the "California Marriage Protection Act."

SECTION 2: Section 7.5 is added to Article I of the California Constitution, to read: SEC. 7.5. Only marriage between a man and a woman is valid or recognized in California. 
2008, California voters passed Proposition 8 by a fifty-two percent margin. ${ }^{14}$ Legal challenges immediately followed. ${ }^{15}$ On May 26, 2009, the California Supreme Court upheld the validity of Proposition 8 as a lawful amendment to the state constitution. ${ }^{16}$ At the same time, it held that Proposition 8 would not apply retroactively, thus sustaining the validity of 18,000 gay and lesbian marriages that occurred between June 2008 and November 2008. ${ }^{17}$ As this Article goes to press, a further legal challenge is pending, as Proposition 8 is now the subject of a controversial federal lawsuit. ${ }^{18}$

Underlying Proposition 8 was an enduring hostility towards one of the most vulnerable minority groups in society. ${ }^{19}$ The decision by the court to uphold Proposition 8 judicially sanctioned the people's decision to

Id. (emphasis in original).

14. Bob Egelko, But Justices Unanimous That 18,000 Couples Married Before Election Remain Wed, S.F. Chron., May 27, 2009, at A1, available at 2009 WLNR 10004887.

15. Id. (discussing challengers' contention that the amendment "was so far-reaching that it was a constitutional revision, which, unlike an amendment, requires legislative approval or a constitutional convention before reaching the ballot").

16. Strauss v. Horton, 207 P.3d 48, 110 (Cal. 2009) (finding Proposition 8 to be a lawful amendment based on the absence of "explicit subject-matter limitation on the use of the initiative to propose and adopt constitutional amendments" as well as the "numerous California precedents interpreting and applying" the distinction between constitutional amendments and revisions).

17. Id. at 119 (holding that Proposition 8 should only be applied prospectively, as the statute does not explicitly provide that it apply retroactively). The marriage of co-author Tiffany Chang was upheld under this provision.

18. See Complaint for Declaratory, Injunctive, or Other Relief, Perry v. Schwarzenegger, No. CV 092292 VRW (N.D. Cal. May 22, 2009), 2009 WL 1490740 (seeking to enjoin the State of California from enforcing Proposition 8 as an unconstitutional violation of gays' and lesbians' Fourteenth Amendment right to equal protection of the law). Plaintiffs argue:

More than 30 years ago, the Supreme Court of the United States recognized that "[m]arriage is one of the 'basic civil rights of man,' fundamental to our very existence and survival." But today, as a result of the passage of Proposition 8 in November 2008 , the State of California denies its gay and lesbian residents access to marriage by providing in its constitution that only a civil marriage "between a man and a woman" is "valid or recognized in California." Instead, California relegates same-sex unions to the separate-but-unequal institution of domestic partnership. This unequal treatment of gays and lesbians denies them the basic liberties and equal protection under the law that are guaranteed by the Fourteenth Amendment to the United States Constitution.

Id. (citations omitted). The filing of the federal lawsuit has spurred controversy, including among gay rights organizations. Maura Dolan, Prop. 8 Foes Clash over Federal Suit, L.A. Times Aug. 9, 2009, at A35, available at 2009 WLNR 15397202.

19. Cf. Erwin Chemerinsky, Challenging Direct Democracy, 2007 МicH. Sт. L. Rev. 293, 297 (2007) (noting the frequency with which the initiative process is used to target minority groups, including sexual orientation minorities). 
strip away a "fundamental right" 20 from a group that the same court had already found to be entitled to the highest level of scrutiny under equal protection analysis. ${ }^{21}$

The court's earlier holding that sexual orientation is a suspect classification, however, survived Proposition 8 , which was silent on that matter, ${ }^{22}$ and may provide a framework for eventual development of equal protection doctrine in other state courts and, ultimately, in the federal courts. $^{23}$

Thus, this Article is designed to highlight an important feature of the Marriage Cases that it might be tempting to overlook in light of the intense focus on Proposition 8 itself and on the later court decision upholding it. As problematic as Proposition 8 was, ${ }^{24}$ the court's May 2008 decision preceding its passage may ultimately prove to be of more longstanding importance than the decision upholding Proposition $8 .{ }^{25}$ That is because the decision upholding Proposition 8 was largely based on the peculiar nature of California's constitutional amendment framework and

20. In re Marriage Cases, 183 P.3d 384, 419 (Cal. 2008) ("[T]he right to marry is a fundamental right whose protection is guaranteed to all persons by the California [c]onstitution."), superseded in part by constitutional amendment, CAL. Const. art. I, \& 7.5, as recognized in Strauss v. Horton, 207 P.3d 48 (Cal. 2009).

21. See generally Strauss, 207 P.3d 48 (upholding the validity of Proposition 8); see also id. at 129 (Moreno, J., dissenting) (pointing out that the majority opinion strips away the right to marry from a minority group).

22. See California Secretary of State, Voter Guide: Text of Proposed Laws 128 (2008), http://voterguide.sos.ca.gov/past/2008/general/text-proposed-laws/text-of-proposed-laws.pdf (amending the California constitution to say only that a valid marriage is between a man and a woman). Because Proposition 8 itself did not address the "classification" of sexual orientation for purposes of judicial equal protection review, the California Supreme Court did not review the issue in Strauss v. Horton. See generally Strauss, 207 P. $3 d 48$.

23. See In re Marriage Cases, 183 P.3d at 444 (trailblazing in equal protection law by recognizing the "suspect classification" of sexual orientation).

24. M. Katherine Baird Darmer, "Activist" Courts, Misleading Wedge Politics and the Tragedy of Proposition 8, 14 Nexus 69, 70 (2008) ("It is an unfortunate feature of democracies that the majority can pass laws that disfavor minority groups.").

25. See, e.g., Kerrigan v. Comm'r of Pub. Health, 957 A.2d 407, 424 (Conn. 2008) (following the precedent set in the Marriage Cases by ruling that same-sex and oppositesex couples are similarly situated and acknowledging marriage as a fundamental right for same-sex couples in Connecticut). The Supreme Court of Connecticut held:

Although we acknowledge that many legislators and many of their constituents hold strong personal convictions with respect to preserving the traditional concept of marriage as a heterosexual institution, such beliefs, no matter how deeply held, do not constitute the exceedingly persuasive justification required to sustain a statute that discriminates on the basis of a quasi-suspect classification.

Id. at 478 . 
will have little precedential force outside California. ${ }^{26}$ The underlying Marriage Cases, however, addressed fundamental questions regarding marriage and the rights of sexual orientation minorities that will continue to be addressed in courts across the country. ${ }^{27}$ The Marriage Cases, thus, have the potential to help shape the jurisprudential debate about rights and equal protection in a landscape in which United States Supreme Court precedent is underdeveloped. ${ }^{28}$

26. See Strauss, 207 P.3d at 60 (noting the relative ease with which the California constitution can be amended and noting that the California constitution has been amended more than five hundred times); Ronald Steiner, Understanding the Prop 8 Litigation: The Scope of Direct Democracy and Role of Judicial Scrutiny, 14 Nexus 81, 84-85 (2009) (describing the relative rarity of California's initiative system). Steiner states that between twenty-one and twenty-three states have initiative systems to change legislation, but only sixteen, including California, allow change by direct initiative. Ronald Steiner, Understanding the Prop 8 Litigation: The Scope of Direct Democracy and Role of Judicial Scrutiny, 14 Nexus 81, 84-85 (2009). He refers to these states as a "distinct minority," and asserts that all of these states have some form of "procedural or substantive constraints." Id.

27. See generally William N. Eskridge, Jr., The Case for Same-Sex Marriage (1996); cf. Andrew E. Taslitz, Judging Jena's D.A.: The Prosecutor and Racial Esteem, 44 HARv. C.R.-C.L. L. Rev. 393, 406-07 (2009) (discussing the various legal and economic advantages to marrying). Professor Taslitz notes that marriage "carries with it a wealth of new rights-presumptive joint ownership of property, access to a portion of the other's social security benefits, inheritance rights, and eased access to joint medical insurance benefits being but a few of the prominent examples." Andrew E. Taslitz, Judging Jena's D.A.: The Prosecutor and Racial Esteem, 44 Harv. C.R.-C.L. L. REv. 393, 406-07 (2009). These benefits are incentives for people to fight for their fundamental right to marriage.

28. Cf. Melissa Murray, Equal Rites and Equal Rights, 96 CAL. L. Rev. 1395, 1403-04 (2008) (noting other ways in which the Marriage Cases were groundbreaking). The California Supreme Court's decision "prompts broader questions about equality, marriage, and the state's role in ensuring equal rights." $I d$. at 1401. Professor Murray states:

Although it will be understood as the case that created gay marriage in California, its legacy is likely to be considerably more broad-and ultimately, more compellingthan this significant development. In making clear the constitutional obligation to ensure equality for all families, the court's decision forces us to confront the important question of how to square marriage with the promise of equal rights and the law's role in structuring family life. In its innovative approach to the question of equal rights, the court not only broadens the available options, it also deepens a conversation about marriage and equality that goes beyond same-sex marriage.

Id. at 1403-04. Regarding the Supreme Court's under-development of jurisprudence in this area, see Part II of this Article. 
The lesbian, gay, bisexual, and transgender (LGBT) ${ }^{29}$ community has long suffered discrimination. ${ }^{30}$ In response, the United States Supreme Court has given grudging protection without explicitly applying a heightened level of scrutiny to cases involving discrimination against the LGBT community, as the California Supreme Court recently did. ${ }^{31}$ LGBTs, thus, remain vulnerable to the whims of majorities in all fifty states. ${ }^{32} \mathrm{~A}$ colleague, who is not a lawyer, summed up this situation in a reflective email:

I sense this feeling of sup[p]ression . . . like something is bubbling just underneath the surface ready to explode. I think that the feelings of depression may be hitting even harder [than] after the election. The public battle pre-election was intense yet there seemed to be something more personal about the [California] Supreme Court hearing. We actually had the opportunity to go inside the courtroom and listen to other human beings argue why [we should] or why we should not have the right to marry. It is very demoralizing to have your rights removed by voters. It is even more demoralizing to have the highest court in the state support the voter's right to remove your

29. While issues of marriage equality are addressed primarily with reference to the gay and lesbian communities, we also refer in this Article to the LGBT communities, which include bisexuals and transgender individuals as well as gays and lesbians, in recognition that all of those communities have suffered discrimination and are in need of more robust legal protections. Where discussing court cases, we attempt to employ the terminology used by those courts in order to give an accurate sense of the scope of protection in various cases.

30. See, e.g., Lawrence v. Texas, 539 U.S. 558, 571 (2003) (“[F]or centuries there have been powerful voices to condemn homosexual conduct as immoral.").

31. See id. (invalidating Texas anti-sodomy law under Due Process Clause analysis without explicitly finding that a "fundamental right" was at issue such as to trigger a formal strict scrutiny analysis); Romer v. Evans, 517 U.S. 620, 631 (1996) (finding that amendment to the Colorado constitution, precluding any type of governmental action to protect homosexuals from discrimination, failed even to meet rational basis requirements). The Romer Court concluded:

We cannot say that Amendment 2 is directed to any identifiable legitimate purpose or discrete objective. It is a status-based enactment divorced from any factual context from which we could discern a relationship to legitimate state interests; it is a classification of persons undertaken for its own sake, something the Equal Protection Clause does not permit.

Romer, 517 U.S. at 635 (indicating that, had the amendment been directed at a "legitimate purpose or discrete objective," rather than at discrimination for its own sake, it might withstand rational basis scrutiny); $c f$. Lawrence, 539 U.S. at 586 (Scalia, J., dissenting) (claiming that the Court applied an "unheard-of form of rational basis review" in evaluating an antisodomy statute). These cases are discussed in more detail in Part II of this Article.

32. See Part II of this Article for further discussion. 
rights and then realize as a tax[-]paying, voting citizen, you have nowhere else to go legally. ${ }^{33}$

Following this introduction, this Article will proceed in four parts. Part II provides a background discussion of the landmark United States $\mathrm{Su}$ preme Court cases dealing with sexual orientation. We then turn, in Part III, to state court decisions in the marriage context, including a focus on the California Supreme Court's 2008 Marriage Cases decision, which declared sexual orientation a suspect classification, eschewed the "immutability" debate, and mandated marriage equality for all Californians. ${ }^{34}$ Part IV will discuss Proposition 8 and the peculiar vulnerability of LGBTs illustrated by that voter initiative. Finally, Part V will provide an analysis of how greater rights may ultimately be achieved in the courts by building upon the California Supreme Court's analysis of the "integral nature" of sexual orientation.

We seek throughout to provide a real-world framework for these issues by relying on our own and others' personal experiences with Proposition 8..$^{35}$ These narrative accounts bolster the California Supreme Court's finding that sexual orientation is "integral" to the self ${ }^{36}$ and animate the need for true equal protection. As a lesbian and co-author of this Article, it has been particularly sobering for Tiffany to realize how her experience with marriage equality has been dictated by the lack of protections for LGBTs:

I have been together with my wife, Lindsey, for five years. After a couple of years, we began thinking about getting married. ... On July 14, 2007, Lindsey and I had our wedding ceremony and reception at our church in Long Beach in front of one hundred of our close friends and family members. Not only was it one of the happi-

33. E-mail from Karla Bland to Katherine Darmer, Professor of Law, Chapman University School of Law (Mar. 13, 2009) (on file with author).

34. See generally In re Marriage Cases, 183 P.3d 384 (Cal. 2008), superseded in part by constitutional amendment, CAL. ConsT. art. I, § 7.5, as recognized in Strauss v. Horton, 207 P.3d 48 (Cal. 2009).

35. See generally William N. Eskridge, Jr., Gaylegal Narratives, 46 STan. L. Rev. 607 (1994) (explaining the importance of "gaylegal" narratives). Gaylegal narratives seek to "[expand] legal debate and [drive] social transformation by illuminating legal issues from the perspectives of nomic groups frequently excluded from political and academic debate, particularly gays and lesbians." Stanford Law Review, Abstract, William N. Eskridge, Jr., Gaylegal Narratives, 46 STAN. L. REv. 607, 607 (1994). According to Professor Eskridge, gaylegal narratives may "be 'beneficial' to the extent that they can speak to audiences with mainstream experiences and values." William N. Eskridge, Jr., Gaylegal Narratives, 46 Stan. L. Rev. 607, 609 (1994).

36. In re Marriage Cases, 183 P.3d at 426. 
est and most significant days of my life, but it also changed my life and relationship for the better.

With our relationship never feeling more solid and secure, we moved to New York shortly after our wedding for my first year of law school. It was in the midst of the cut-throat world of finding an apartment to rent in and around New York City that reality hit again-the protection I felt from my marriage ceremony was not a legally tangible protection. Despite our scrambling to prove we were a legitimate couple, including our domestic partnership paperwork, landlords insisted that we each separately meet the annual income requirement. Without a legal marriage certificate, we were deemed to be no more than "roommates." Although we met the financial threshold as a family, it was impossible for me to do so individually as a new law student. With my dignity tucked away, I had to ask my brother to co-sign my portion of the lease agreement, and we had to pay additional months in advance. We paid over $\$ 10,000$ to get our foot into the door of a one-bedroom apartment; it would have been half that amount if we had been able to get legally married.

Nine months later, on May 15, 2008, the California Supreme Court ruled in favor of marriage equality. For our one-year wedding anniversary, Lindsey and I flew back to California to get our official marriage license. The county clerk who represented the local and state government recognized our relationship, validated our marriage, and even took our picture for us. Walking out of the clerk's office, I felt a level of protection and equality that $I$ think is impossible to know exists until you have experienced it. One month later, we moved back to California to enjoy having a legal status that was equal to our neighbors. And sure enough, our car insurance premium was reduced by half when our agent figured out that we were legally married. In that small gesture, we realized that gay and lesbian people were finally gaining equality and that this recognition of gay and lesbian relationships meant that we did not have to worry quite as much about every detail of our future together.

We enjoyed this newfound equality for only a few months before a bare majority of voters chose to strip gays and lesbians of a basic civil right and their human dignity and to write this discrimination into the California constitution. When I awoke to the shocking and reprehensible news that Proposition 8 had passed, I felt like someone punched me in the stomach and knocked the wind right out of me. For the first few days, I cried; I was depressed, I barely went to my classes, and I dreaded seeing anyone. And for a week or so after the election, I found myself unable to look at strangers in the eye. I literally looked down when I was passing someone on the sidewalk. 
Part of it was anger, thinking that perhaps that person voted to strip my wife and me of our rights, and part of it was humiliation that people might be thinking, "See, you were wrong, you are less than me." It is strange to consider that on November 3, 2008, I was enjoying all the rights of a full California citizen for the first time in my life, and one day later, I was relegated to being a second-class citizen. Although my marriage is currently considered valid, I still worry when Lindsey is out without me, or when we hold hands in public, of what abuse others will feel entitled to commit after the codifying of discrimination into the constitution. I worry that in a year and a half, when I must take an oath to be admitted to the state bar, I will have to decide between surrendering my livelihood as an attorney in California or swearing an oath to support a constitution that discriminates against me and my family.

There has been one common and striking observation each time I have told my personal story about how the give and take of my fundamental right to marry has affected my life. That observation is that the tears from so many in the audience listening were not for my hardships, but because my story echoed the pain that they have felt and endured in silence up until that point.

\section{LGBT Rights in the United States Supreme Court}

The Fourteenth Amendment of the United States Constitution contains the provision: "[N]or shall any State deprive any person of life, liberty, or property, without due process of law; nor deny to any person within its jurisdiction the equal protection of the laws." 37 While the language of the Due Process and Equal Protection Clauses is plain, the long history of civil rights movements in this country has shown group after group battle for the recognition of their rights and equality. ${ }^{38}$ On many occasions, it has been necessary for the Supreme Court to articulate elevated federal protections for a group that would otherwise face discrimination and inequity when subject to the whims of the majority. ${ }^{39}$

37. U.S. Const. amend. XIV, $\S 1$.

38. See, e.g., Frontiero v. Richardson, 411 U.S. 677, 685 (1973) (discussing the struggle for civil rights for women); Reynolds v. Sims, 377 U.S. 533, 554-55 (1964) (explaining attacks on voting rights for minorities); see also M. Katherine Baird Darmer, "Activist" Courts, Misleading Wedge Politics and the Tragedy of Proposition 8, 14 Nexus 69, 70 (2009) (noting that "[ $\mathrm{t}]$ hroughout this country's history, minority groups have ... resorted to the courts to gain rights guaranteed by our federal and state constitutions").

39. See, e.g., City of Cleburne v. Cleburne Living Ctr., Inc., 473 U.S. 432, 440 (1985) (applying strict scrutiny review to race-based discrimination); Craig v. Boren, 429 U.S. 190, 197 (1976) (applying heightened scrutiny analysis to gender-based discrimination). According to Justice Thurgood Marshall, the strict requirements of strict scrutiny review 
Under the Equal Protection Clause, a law that discriminates against a particular group of people is subject to one of three levels of scrutiny"rational basis" review, "intermediate scrutiny," or "strict scrutiny." While most laws are subject to only rational basis analysis, which gives great deference to the state's actions, those that discriminate against a "suspect" or "quasi-suspect" class receive at least a heightened level of scrutiny. ${ }^{41}$ For a quasi-suspect classification, such as gender, the State must show that the law is substantially related to an important government interest in order to pass intermediate, or heightened, scrutiny. ${ }^{42}$ For a suspect classification, such as race, the State must show that the law is narrowly tailored to address a compelling state interest in order to pass strict scrutiny review. ${ }^{43}$ Under the Due Process Clause, a law that impacts a "fundamental right" is also subject to strict scrutiny review. ${ }^{44}$

make such review "strict in theory, but fatal in fact" to almost all race-based categorizations. Fullilove v. Klutznick, 448 U.S. 448, 519 (198C) (Marshall, J., concurring).

40. See, e.g., Romer v. Evans, 517 U.S. 620, 633 (1996) (applying rational basis review, which requires that the law be rationally related to a legitimate governmental interest, to a case involving discrimination against homosexuals); City of Cleburne, 473 U.S. at 440 (noting that statutes that classify by "race, alienage or national origin" must be "suitably tailored to serve a compelling state interest"); Craig, 429 U.S. at 197 (finding that "classifications by gender must serve important governmental objectives and must be substantially related to achievement of those objectives" under heightened scrutiny review).

41. See, e.g., City of Cleburne, 473 U.S. at 440; Craig, 429 U.S. at 197.

42. United States v. Virginia (VMI), 518 U.S. 515, 532-33 (1996) (discussing the different standards of review used in gender discrimination cases, as compared with those used in racial discrimination cases); Miss. Univ. for Women v. Hogan, 458 U.S. 718, 724 (1982) (applying an intermediate test for a state statute that excluded males from enrolling in a state-supported school for nursing).

43. See, e.g., City of Cleburne, 473 U.S. at 440.

The general rule [mandating rational basis review] gives way, however, when a statute classifies by race, alienage, or national origin. These factors are so seldom relevant to the achievement of any legitimate state interest that laws grounded in such considerations are deemed to reflect prejudice and antipathy-a view that those in the burdened class are not as worthy or deserving as others. For these reasons and because such discrimination is unlikely to be soon rectified by legislative means, these laws are subjected to strict scrutiny and will be sustained only if they are suitably tailored to serve a compelling state interest.

Id. (citations omitted).

44. E.g., San Antonio Indep. Sch. Dist. v. Rodriguez, 411 U.S. 1, 17 (1973) (stating that infringement upon a fundamental right under the Due Process Clause is subject to strict scrutiny review); see also Lawrence v. Texas, 539 U.S. 558, 586 (2003) (Scalia, J., dissenting) (noting that the majority had not explicitly found a "fundamental right" at issue in overturning Texas anti-sodomy law); Romer, 517 U.S. at 625-26 (noting that the Colorado Supreme Court rejected an amendment to the Colorado constitution that banned state legislation prohibiting discrimination against homosexuals because it infringed on the "fundamental right of gays and lesbians to participate in political process," but it did so under equal protection review). 
When the Supreme Court has applied heightened scrutiny, the practical result has been an expansion of civil rights for the affected group. ${ }^{45}$ For example, after the Court found that race was a suspect classification requiring the highest level of judicial scrutiny in Korematsu v. United States, ${ }^{46}$ the Court decided Brown v. Board of Education and Loving $v$. Virginia, respectively striking down school segregation and anti-miscegenation laws. ${ }^{47}$ Subsequently, the Supreme Court held in Craig v. Boren that gender was a "quasi-suspect" classification requiring a heightened level of scrutiny. ${ }^{48}$

It was not until the 1990s that the Court began to recognize the rights of sexual orientation minorities. ${ }^{49}$ Before discussing the Supreme Court cases that have shaped the federal legal landscape for those rights, a summary of Bowers v. Hardwick provides necessary background. ${ }^{50}$

Michael Hardwick was arrested for sodomy when a police officer entered his home and found him engaging in oral sex with another man. ${ }^{51}$ Hardwick challenged the Georgia anti-sodomy law, which prohibited oral and anal sex between both different-sex and same-sex couples, arguing that the right to privacy is implicit in the Fourteenth Amendment and protects personal liberty in private sexual matters. ${ }^{52}$ The Supreme Court rejected this argument and held that "homosexual sodomy" was not a

45. See, e.g., Craig, 429 U.S. at 197 (applying heightened scrutiny to invalidate a gender discriminatory law); Loving v. Virginia, 388 U.S. 1, 8-9 (1967) (applying the strictest scrutiny to strike down Virginia's anti-miscegenation law).

46. Korematsu v. United States, 323 U.S. 214, 216 (1944). Despite its finding that race was a suspect classification requiring strict scrutiny, the Court upheld the forced internment of Japanese-Americans during World War II, rationalizing that "[p]ressing public necessity may sometimes justify the existence of such restrictions [but] racial antagonism never can." Id.

47. Loving, 388 U.S. at 11-12 (invalidating anti-miscegenation law in Virginia); Brown v. Bd. of Educ., 347 U.S. 483, 495 (1954) (compelling integration of public schools in Kansas).

48. Craig, 429 U.S. at 199 (nullifying an Oklahoma law permitting women to purchase $3.2 \%$ beer at age eighteen, while men could not do so until age twenty-one).

49. See Romer, 517 U.S. at 635 (rejecting an amendment to the Colorado constitution that would have precluded protection from discrimination based upon sexual orientation). The Court found in Romer, "We must conclude that Amendment 2 classifies homosexuals not to further a proper legislative end but to make them unequal to everyone else. This Colorado cannot do." Id.

50. Bowers v. Hardwick, 478 U.S. 186, 195 (1986) (finding no constitutional right to engage in "homosexual sodomy" and upholding anti-sodomy laws), overruled by Lawrence v. Texas, 539 U.S. 558 (2003).

51. Id. at $187-88$.

52. Id. at 188 n.1, 195 (describing the Georgia statute and Hardwick's grounds for challenging its constitutionality). While Hardwick likened his case to Stanley v. Georgia, in which the United States Supreme Court overturned a ban on possessing obscene materials in the privacy of one's home, the Court distinguished Stanley as "firmly grounded in the 
fundamental right. ${ }^{53}$ As such, the Court found that the Georgia anti-sodomy law was constitutional because enforcing morality was a legitimate government interest, thereby allowing the law to survive a rational basis analysis. ${ }^{54}$ And that is where LGBT constitutional rights stood in the Supreme Court for the next decade. ${ }^{55}$

In 1996, the Court issued an important opinion in Romer v. Evans. ${ }^{56}$ In that decision, the Court rejected an effort by the State of Colorado to deny gays and lesbians the protections of anti-discrimination laws via a statewide referendum repealing then-existing anti-discrimination laws and precluding similar laws from future enactment. ${ }^{57}$ Writing for a six-tothree majority, Justice Kennedy declared, "A State cannot so deem a class of persons a stranger to its laws." 58 Finding the law invalid under the Equal Protection Clause, the Court invoked only the rational basis test in lieu of upholding the state court's finding that strict scrutiny was the appropriate test for a case involving impairment of a fundamental right of gays and lesbians. ${ }^{59}$ The conclusion that the amendment failed

First Amendment," rather than the Fourteenth Amendment. Id. at 195; see also generally Stanley v. Georgia, 394 U.S. 557 (1969).

53. Bowers, 478 U.S. at 191-92 (stating that because homosexual sodomy is neither "implicit in the concept of ordered liberty," nor "deeply rooted in this Nation's history and tradition," it is not a fundamental right (citations omitted)).

54. Id. at 196 ("The law, however, is constantly based on notions of morality, and if all laws representing essentially moral choices are to be invalidated under the Due Process Clause, the courts will be very busy indeed."). The Court invoked the "slippery slope" admonition, warning that prohibiting sodomy laws would make it "difficult, except by fiat, to limit the claimed right to homosexual conduct while leaving exposed to prosecution adultery, incest, and other sexual crimes even though they are committed in the home." Id. at 195-96. Accordingly, the Court stated, "We are unwilling to start down that road." Id. at 196.

55. American Civil Liberties Union, ACLU and the History of LGBT Rights \& HIV/ AIDS, http://www.aclu.org/lgbt/gen/24578res20060316.html (last visited Aug. 3, 2009) (providing a timeline of "major events and legal cases in [the LGBT community's] civil rights struggle").

56. Romer v. Evans, 517 U.S. 620, 635-36 (1996).

57. Id.

58. Id. at 635 (arguing that the Colorado amendment's legislative end was not only improper, but served to make homosexuals "unequal to everyone else").

59. Id. at 625 (explaining that "the [s]tate [s]upreme [c]ourt held that Amendment 2 was subject to strict scrutiny under the Fourteenth Amendment because it infringed the fundamental right of gays and lesbians to participate in the political process" (citation omitted)). The Court reasoned that "if a law neither burdens a fundamental right nor targets a suspect class, [the Court] will uphold the legislative classification so long as it bears a rational relation to some legitimate end." Id. at 631 (citation omitted). Even under this "conventional inquiry," the Court found that Amendment 2 did not further a legitimate governmental goal. Id. at 632 . 
even under rational basis review has limited the impact of the Court's holding in other contexts. ${ }^{60}$

In reaching its decision that the amendment failed equal protection requirements, the Romer Court rejected Colorado's primary argument that the amendment precluded extension of only "special rights" based upon sexual orientation. ${ }^{61}$ Rather, the Court found that "the amendment imposes a special disability upon [homosexual] persons alone." 62 Indeed, the Court noted that "[h]omosexuals are forbidden the safeguards that others enjoy or may seek without constraint" and that "[t]hese are protections taken for granted by most people either because they already have them or do not need them."63 The Court also rejected two other arguments for Amendment 2: first, that it was rooted in the right to freedom of association under the First Amendment; and second, that it was an effort to conserve government resources to combat discrimination against other groups. ${ }^{64}$ Repealing and preventing any future legislation that protects a particular disadvantaged group, the Court concluded, was too far removed to bear a rational relation to those stated government interests. $^{65}$

Justice Kennedy wrote in the Romer decision that "if the constitutional conception of "equal protection of the laws" means anything, it must at the very least mean that a bare . . . desire to harm a politically unpopular group cannot constitute a legitimate governmental interest." "66 Moreover, the Colorado amendment was "a classification of persons undertaken for its own sake, something the Equal Protection Clause does not permit." 67 The Court, thus, found that such animus-based lawmaking

60. See, e.g., In re Marriage Cases, 183 P.3d 384, 442 n.60 (Cal. 2008) (listing state court cases in which sexual orientation was found not to be a "suspect" categorization requiring heightened review in equal protection challenges), superseded in part by constitutional amendment, CAL. CoNsT. art. I, § 7.5, as recognized in Strauss v. Horton, 207 P.3d 48 (Cal. 2009).

61. Romer, 517 U.S. at 631 ("We find nothing special in the protections Amendment 2 withholds.").

62. Id.

63. Id.

64. Id. at 635 (finding, to the contrary, no legitimate governmental objective to justify the disparate treatment of homosexuals under Colorado's Amendment 2). " [C]lass legislation ... [is] obnoxious to the prohibitions of the Fourteenth Amendment.' ..." Id. (citing Civil Rights Cases, 109 U.S. 3, 24 (1883)).

65. Id. ("The breadth of the amendment is so far removed from these particular justifications that we find it impossible to credit them.").

66. Romer, 517 U.S. at 634 (quoting Dep't of Agric. v. Moreno, 413 U.S. 528, 534 (1973)) (emphasis in original).

67. Id. at 635 . 
was illegitimate. 68 As one scholar noted, the focus on "animus" was "remarkable" because "it is the only time the Court has used that word to invalidate a law under equal protection."69

In a strongly-worded dissent, Justice Scalia took issue with the Romer Court's analysis and disagreed with the majority's rejection of moral opprobrium as a legitimate basis for discriminatory legislation. ${ }^{70}$ In his dissent, Scalia argued that Amendment 2 merely prohibited giving "special rights" based upon sexual orientation, while leaving intact the baseline protection that all Colorado citizens are afforded under the Colorado constitution. $^{71}$ Scalia argued that the anti-discrimination laws at issue simply made it more difficult for a group to receive "preferential" treatment and that this was not a violation of equal protection. ${ }^{72}$ The dissent also contended that enforcing public sexual morality was a legitimate government interest to which Amendment 2 was rationally related. ${ }^{73}$ In

68. Id. at 632 ("[The Amendment's] sheer breadth is so discontinuous with the reasons offered for it that the amendment seems inexplicable by anything but animus toward the class it affects; it lacks a rational relationship to legitimate state interests.").

69. Sharon E. Rush, Whither Sexual Orientation Analysis? The Proper Methodology when Due Process and Equal Protection Intersect, 16 WM. \& MARY BILL RTs. J. 685, 718 (2008). The author notes, however, that the Romer Court's singular use of the term "animus" did not announce a new rule that all animus-based legislation is per se unconstitutional. Id. Rather, Colorado's Amendment 2 could not stand because "no other legitimate purpose could justify it." Id.

70. Romer, 517 U.S. at 636 (Scalia, J., dissenting) (arguing that the amendment was not an attempt to harm homosexuals, but rather it was a "modest attempt by seemingly tolerant Coloradans to preserve traditional sexual mores against the efforts of a politically powerful minority to revise those mores through use of the laws").

71. Id. at 638 (stating that "the clear import of the Colorado [amendment] is that 'general laws and policies that prohibit arbitrary discrimination' would continue to prohibit discrimination on the basis of homosexual conduct as well").

72. Id. ("The amendment prohibits special treatment of homosexuals, and nothing more." (emphasis in original)). Scalia elaborated as follows:

It would not affect, for example, a requirement of state law that pensions be paid to all retiring state employees with a certain length of service; homosexual employees, as well as others, would be entitled to that benefit. But it would prevent the State or any municipality from making death-benefit payments to the "life partner" of a homosexual when it does not make such payments to the long-time roommate of a nonhomosexual employee. Or again, it does not affect the requirement of the State's general insurance laws that customers be afforded coverage without discrimination unrelated to anticipated risk. Thus, homosexuals could not be denied coverage, or charged a greater premium, with respect to auto collision insurance; but neither the State nor any municipality could require that distinctive health insurance risks associated with homosexuality (if there are any) be ignored.

Id.

73. Id. at 652 . 
Scalia's view, the majority opinion flew in the face of precedents, such as Bowers v. Hardwick and Davis v. Beason. ${ }^{74}$

Justice Scalia further pointed out that it was irreconcilable that a law preventing preferential treatment of persons with a tendency to engage in sodomy could be held unconstitutional when laws criminalizing sodomy were upheld as constitutional in Bowers. ${ }^{75}$ Scalia wrote that he would have upheld Amendment 2, deferring to the "legitimate government interest" of honoring the public majority's decision to voice their moral disapproval of homosexual conduct by denying homosexuals "special rights." 76

Seven years later, in Lawrence $v$. Texas, the Supreme Court directly confronted its prior holding in Bowers. ${ }^{77}$ In Lawrence, John Geddes Lawrence and Tyron Garner, both male adults, were arrested for having consensual sex with one another when police entered Lawrence's home in response to a reported weapons disturbance. ${ }^{78}$ The men were charged with and convicted of violating a Texas statute prohibiting sexual intercourse between people of the same sex, ${ }^{79}$ a conviction that was sustained

74. Id. at 649-50 (citing Bowers v. Hardwick, 478 U.S. 186, 190 (1986) (upholding Georgia sodomy ban), overruled by Lawrence v. Texas, 539 U.S. 558, 578 (2003); Davis v. Beason, 133 U.S. 333, 346-47 (1890) (endorsing Idaho law prohibiting polygamists and bigamists from voting)).

75. Romer, 517 U.S. at 642 (Scalia, J., dissenting) (stating that "if it is rational to criminalize the conduct, surely it is rational to deny special favor and protection to those with a self-avowed tendency or desire to engage in the conduct").

76. Id. at 653. According to Scalia:

Amendment 2 is designed to prevent piecemeal deterioration of the sexual morality favored by a majority of Coloradans, and is not only an appropriate means to that legitimate end, but a means that Americans have employed before. Striking it down is an act, not of judicial judgment, but of political will. Id.

77. Lawrence, 539 U.S. at 564 (overturning Texas law criminalizing "deviate sexual intercourse" between consenting adults and, thereby, overruling Bowers). The Court concluded that:

[T] he case should be resolved by determining whether the petitioners were free as adults to engage in the private conduct in the exercise of their liberty under the Due Process Clause of the Fourteenth Amendment to the Constitution. For this inquiry we

deem it necessary to reconsider the Court's holding in Bowers.

Id. (citing Bowers, 478 U.S. at 196 (upholding Georgia sodomy ban)).

78. $I d$. at $562-63$.

79. Id. at 563 ("The complaints described their crime as 'deviate sexual intercourse, namely anal sex, with a member of the same sex (man)." ). Lawrence and Garner challenged their convictions under the Equal Protection Clauses of both the United States Constitution and the Texas constitution. Id. For an extended discussion of Lawrence, see William N. Eskridge, Jr., Dishonorable Passions: Sodomy laws in America, 1861-2003 299-330 (2008). 
by the state appeals court pursuant to the precedent set in Bowers $v$. Hardwick. ${ }^{80}$

The Supreme Court invalidated the convictions on due process grounds, and the majority briefly explained why it did not rely upon the Equal Protection Clause. ${ }^{81}$ While acknowledging that equal protection was a "tenable argument," the Court recognized that Bowers v. Hardwick could be distinguished because that case dealt with an anti-sodomy law applicable to both same-sex and opposite-sex couples. ${ }^{82}$ Deciding Lawrence based on the Equal Protection Clause would have left Bowers as good law, thereby permitting similarly discriminatory penal provisions as long as they applied to opposite-sex as well as same-sex couples. ${ }^{83}$ Instead, the Court focused on the Due Process Clause, explaining that the majority in Bowers erroneously framed the issue as being about the right to engage in particular sexual conduct rather than about a person's right to privacy-including the right to privacy in intimate sexual behavior. ${ }^{84}$ According to the Court, "To say that the issue in Bowers was simply the right to engage in certain sexual conduct demeans the claim the individual put forward, just as it would demean a married couple were it to be

80. Lawrence v. State, 41 S.W.3d 349, 355 (Tex. App.-Houston [14th Dist.] 2001) (applying Bowers, rather than Romer, in upholding the Texas statute), rev'd, 539 U.S. 558 (2003). The Texas appeals court explicitly found that Romer did not protect Lawrence and Garner:

Romer provides no support for appellants' position. Romer, for example, does not disavow the Court's previous holding in Bowers; it does not elevate homosexuals to a suspect class; it does not suggest that statutes prohibiting homosexual conduct violate the Equal Protection Clause; and it does not challenge the concept that the preservation and protection of morality is a legitimate state interest.

Id.

81. Lawrence, 539 U.S. at 574-75.

82. Id. at 575 .

83. Id. (pointing out that due process analysis in Lawrence would allow the Court to determine that Bowers had "continuing validity"). The Court also noted:

If protected conduct is made criminal and the law which does so remains unexamined for its substantive validity, its stigma might remain even it if were not enforceable as drawn for equal protection purposes. When homosexual conduct is made criminal by the law of the State, that declaration in and of itself is an invitation to subject homosexual persons to discrimination both in the public and in the private spheres. The central holding of Bowers has been brought into question by this case; and it should be addressed. Its continuance as precedence demeans the lives of homosexual persons. Id.

84. Id. at 578 (citing Bowers v. Hardwick, 478 U.S. 186, 216 (1986) (Stevens, J., dissenting), overruled by Lawrence v. Texas, 539 U.S. 558 (2003)) (explaining that Justice Stevens's dissent in Bowers, in which he argued that the case was truly about the right to privacy, should have controlled the majority's decision in Bowers and did control the decision in Lawrence). 
said marriage is simply about the right to have sexual intercourse." 85 Dispatching Bowers, Justice Kennedy wrote: "Bowers was not correct when it was decided, and it is not correct today. It ought not to remain binding precedent. Bowers $v$. Hardwick should be and now is overruled."86 Finding that there was no legitimate governmental interest to justify the Texas law, the Court held that private sexual conduct between two consenting adults is a protected liberty interest under the Due Process Clause. ${ }^{87}$

Justice O'Connor concurred with the Lawrence majority in a separate opinion, arguing that the Texas anti-sodomy law should have been invalidated under the Equal Protection Clause, leaving Bowers intact. ${ }^{88}$ Relying on a rationale similar to that of the Romer majority, Justice O'Connor applied rational basis analysis to reject a law that sought to target and harm a particular group based upon the majority's moral disapproval of that group's nature or conduct. ${ }^{89}$ Justice O'Connor found the State's argument that the Texas law targeted only certain conduct, rather than gays and lesbians themselves, unconvincing. ${ }^{90}$ Rather, because the conduct was so intimately related to gays and lesbians, it inevitably targeted that

85. Id. at 567.

86. Lawrence, 539 U.S. at 578.

87. Id. at 578-79 (explaining that because the petitioners were not minors and were not injured or coerced into the prohibited sexual act, they were entitled to privacy from governmental intrusion). The Court stated:

The petitioners are entitled to respect for their private lives. The State cannot demean their existence or control their destiny by making their private sexual conduct a crime. Their right to liberty under the Due Process Clause gives them the full right to engage in their conduct without intervention of the government.

Id. at 578 .

88. Id. at 579 (O'Connor, J., concurring).

89. Id. at 580-83 (explaining that the Court has "been most likely to apply rational basis review to hold a law unconstitutional under the Equal Protection Clause where, as here, the challenged legislation inhibits personal relationships" and that "[m]oral disapproval of a group cannot be a legitimate governmental interest"). O'Connor continued:

A law branding one class of persons as criminal based solely on the State's moral disapproval of that class and the conduct associated with that class runs contrary to the values of the Constitution and the Equal Protection Clause, under any standard of review. I therefore concur in the Court's judgment that Texas' sodomy law banning "deviate sexual intercourse" between consenting adults of the same sex, but not between consenting adults of different sexes, is unconstitutional.

Id. at 585 .

90. Id. at 583 (noting that, while it was true that only the conduct was being penalized, this was conduct that was closely related to and perceived as homosexual behavior). In fact, $O^{\prime}$ Connor wrote that Texas admitted that the law criminalizing sodomy created the perception in the state that simply being gay or lesbian was a crime. Id. at 583-84 ("In Texas, calling a person a homosexual is slander per se because the word 'homosexual' 'impute[s] the commission of a crime." (emphasis in original) (citations omitted)). 
group. ${ }^{91}$ But, straying from a straightforward, traditional rational basis approach, O'Connor stated, "When a law exhibits such a desire to harm a politically unpopular group, we have applied a more searching form of rational basis review to strike down such laws under the Equal Protection Clause."92 O'Connor also explicitly stated, however, that there may be times that classification based on sexual orientation would be permissible under the rational basis standard. ${ }^{93}$ Of particular current relevance, O'Connor cited "national security or preserving the traditional institution of marriage" as examples of potentially legitimate state interests. ${ }^{94}$

In the primary dissenting opinion, Justice Scalia argued against overruling Bowers, disagreed with the majority that the Texas anti-sodomy law violated the Due Process Clause, and argued that Justice O'Connor's conclusion that the law failed under the Equal Protection Clause was wrong. ${ }^{95}$ Scalia persisted in framing the issue narrowly-considering only the right to engage in homosexual sodomy-rather than focusing on a more broadly articulated privacy right. ${ }^{96}$ In her recent article, Professor

91. Lawrence v. Texas, 539 U.S. 558, 583 (2003) (O'Connor, J., concurring) ("[The law] is ... directed toward gay persons as a class.").

92. Id. at 580 (emphasis added). For a discussion of the concept of a de facto but unacknowledged heightened scrutiny, or "rational basis with bite," see Jeremy B. Smith, Note, The Flaws of Rational Basis with Bite: Why the Supreme Court Should Acknowledge Its Application of Heightened Scrutiny to Classifications Based on Sexual Orientation, 73 ForDHAM L. REV. 2769 (2005).

93. Lawrence, 539 U.S. at 585 (O'Connor, J., concurring) ("That this law as applied to private, consensual conduct is unconstitutional under the Equal Protection Clause does not mean that other laws distinguishing between heterosexuals and homosexuals would similarly fail under rational basis review.").

94. Id.

95. Id. at 586-88 (Scalia, J., dissenting) (claiming that whether or not the Texas law targeted homosexuals, the undisputed history of criminalizing sodomy in general preempts a finding that homosexual sodomy is a fundamental right, as a fundamental right is defined as "deeply rooted in our Nation's history and tradition"). Because there was no fundamental right that would invoke heightened scrutiny, Scalia argued that moral disapproval of certain sexual conduct was a legitimate government interest sufficient to satisfy the rational basis test used in the majority's due process analysis and the equal protection analysis suggested by O'Connor. Id. at 593 . Scalia gave examples of existing laws criminalizing "fornication, bigamy, adultery, adult incest, bestiality, and obscenity," which were based on sexual morality and would also presumably fail a rational basis test after Lawrence. Id. at 599. Additionally, Scalia suggested that there was no equal protection violation in Lawrence because the Texas law equally prohibited all people-both heterosexuals and homosexuals from engaging in sexual acts with someone of the same sex. Id. at 599-600. Distinguishing Lawrence from the anti-miscegenation cases, Scalia argued that, while a "racially discriminatory purpose is always sufficient to subject a law to strict scrutiny," only rational basis review applies in cases like Lawrence, involving discrimination based on sexual orientation. Id. at 600 .

96. Id. at 586 ("[N]owhere does the Court's opinion declare that homosexual sodomy is a 'fundamental right' under the Due Process Clause; nor does it subject the Texas law to 
Sharon Rush identifies this approach to the issue as the "collapsible error," in which the "underlying right is defined by the group targeted by the law." 97

Scalia's protests notwithstanding, in Romer and Lawrence, the Supreme Court provided sexual orientation minorities limited protections under the Fourteenth Amendment. ${ }^{98}$ But the framework the Court provided has led to inconsistencies in the lower courts. ${ }^{99}$ Neither Romer, in the equal protection context, nor Lawrence, using a due process analysis, purported to apply any form of heightened scrutiny. ${ }^{100}$ Yet the Court rejected both Colorado's amendment targeted at sexual orientation and Texas's anti-sodomy law, leading some to conclude that the Court applied de facto heightened scrutiny under what has been sometimes termed "rational basis with bite."101 In a recent article, one scholar explores the consequences of "rational basis with bite" in the sexual orientation context after Romer and Lawerence. ${ }^{102}$ He demonstrates that this phantom level of scrutiny has led many lower federal courts to ignore the protec-

the standard of review that would be appropriate (strict scrutiny) if homosexual sodomy were a "fundamental right." (emphasis in original)).

97. Sharon E. Rush, Whither Sexual Orientation Analysis? The Proper Methodology when Due Process and Equal Protection Intersect, 16 WM. \& MARY Bill RTs. J. 685, 743 (2008). Rush explains:

Courts commit the Collapsible Error when they conflate the equal protection question ("Are gays a suspect class?") into the due process question ("Is there an underlying fundamental right?") by defining the underlying right by the group targeted by the law-gay marriage-and then limiting the analysis to substantive due process ("Is there a fundamental right to gay marriage?").

Id. This tendency is reflected in cases addressing marriage rights for same-sex couples: courts frame the issue as whether same-sex couples have a right to "gay marriage," rather than asking whether same-sex couples have a right to marriage. See generally id.

98. See generally Lawrence, 539 U.S. 558; Romer v. Evans, 517 U.S. 620 (1996).

99. See Jeremy B. Smith, Note, The Flaws of Rational Basis with Bite: Why the Supreme Court Should Acknowledge Its Application of Heightened Scrutiny to Classifications Based on Sexual Orientation, 73 Fordham L. Rev. 2769, 2770 (2005).

100. See generally Lawrence, 539 U.S. 558; Romer, 517 U.S. 620.

101. See, e.g., Richard H. Fallon, Jr., Some Confusions About Due Process, Judicial Review, and Constitutional Remedies, 93 Colum. L. Rev. 309, 316-17 (1993) ("When government draws classificatory lines that are likely to stigmatize or that come close to trenching on other protected rights, the Supreme Court, within both substantive due process and equal protection frameworks, has sometimes given its rational basis review enhanced bite." (footnotes omitted)).

102. Jeremy B. Smith, Note, The Flaws of Rational Basis with Bite: Why the Supreme Court Should Acknowledge Its Application of Heightened Scrutiny to Classifications Based on Sexual Orientation, 73 FordHam L. Rev. 2769, 2770 (2005) (citing Gayle Lynn Pettinga, Note, Rational Basis with Bite: Intermediate Scrutiny by Any Other Name, 62 IND. L.J. 779, 780 (1987) for use of the term) (arguing that the Supreme Court should acknowledge that heightened scrutiny was applied in both Romer and Lawrence so that lower courts will not be trepid about applying this more searching review). 
tive implications of Romer and Lawrence while simply "apply[ing] traditional rational basis review without examining whether the classification at issue may be based on animus or on notions of majoritarian morality without a true legitimate governmental interest."103

On the other hand, some state courts have been less hesitant to invoke "rational basis with bite," applying a more searching form of scrutiny than mere rational basis review, but without explicitly applying heightened scrutiny. ${ }^{104}$. The extension of greater protections in these cases, however, was largely the result of state courts interpreting more flexible and protective state constitutions. ${ }^{105}$ Despite elevated protections in some states, a lack of adequate federal protection has left LGBTs vulnerable to discriminatory laws that may be upheld under a rational basis test. ${ }^{106}$ Smith suggests that, in order to relieve the inconsistency created by the Supreme Court's opacity, the Court must explicitly acknowledge the heightened scrutiny analysis that was implemented, de facto, in both Romer and Lawrence. ${ }^{107}$ While Justice O'Connor's concurrence in Lawrence hints at this by referencing "a more searching form of rational basis review," 108 the current state of federal jurisprudence leaves LGBTs vulnerable to unchecked, discriminatory legislation. This has been illus-

103. Id. at 2785 .

104. Id. at 2796-97 (citing Goodridge v. Dep't of Pub. Health, 798 N.E.2d 941 (Mass. 2003); Baker v. State, 744 A.2d 864 (Vt. 1999)).

105. Id at 2796 (pointing out that these state constitutions allow for "greater flexibility" in applying "rational basis with bite"). Writing in 2005, Smith notes:

Other jurisdictions have also dealt with the right of gay men and lesbians to marry at some level, including Alaska, Arizona, California, Hawaii, New Jersey, New York, and Washington, D.C. These cases have reached different conclusions based on different grounds - often due process or other idiosyncrasies of their respective state constitutions-but none have used heightened scrutiny based on sexual orientation.

$I d$. at n.229. Other state court opinions have explicitly relied upon heightened scrutiny in sexual orientation discrimination cases. Id. at 2800-04 (citing Tanner v. Or. Health Sciences Univ., 971 P.2d 435 (Or. Ct. App. 1998); Castle v. State, No. 04-2-00614-4, 2004 WL 1985215 (Wash. Super. Ct. Sept. 7, 2004)). Other state court opinions have explicitly replied upon heightened scrutiny in sexual orientation discrimination cases. Id. at 2800-04 (citing Tanner, 971 P.2d 435; Castle, 2004 WL 1985215).

106. See id. at 2785.

107. Jeremy B. Smith, Note, The Flaws of Rational Basis with Bite: Why the Supreme Court Should Acknowledge Its Application of Heightened Scrutiny to Classifications Based on Sexual Orientation, 73 Fordham L. Rev. 2769, 2813 (2005) (explaining that the Supreme Court must explicitly designate heightened scrutiny as the appropriate analysis for cases involving sexual orientation discrimination in order for lower courts to apply this rationale appropriately and consistently). "The rational basis with bite approach . . . though successful in striking down classifications based on sexual orientation, is also unsatisfactory due to the courts' failure to acknowledge explicitly their use of heightened scrutiny and thereby opening up those decisions to compelling criticism." Id. at 2812 .

108. Lawrence v. Texas, 539 U.S. 558, 580 (2003) (O'Connor, J., concurring). 
trated most recently in the fight for marriage equality as well as in the recent anti-adoption initiative in Arkansas. ${ }^{109}$

\section{Marriage Equality in the States}

"Laura and I were married on August 8, 2008. In front of family and friends, some of whom flew in from Texas and New York, we were allowed to remove the label of second class citizen. Being married . . gave us a sense of protection that neither one of us felt before. Our love and commitment . . . seemed even stronger and deeper afterwards."

$$
\text { -Karla Bland }{ }^{110}
$$

"What an incredible day that was for us, our two children, our family and our friends. We were so happy that our children would be able to say that their parents were 'married' just as their friends are able to say. It meant a lot to both of us for our children to be seen as equals with their peers."

$$
\text { -Jeffrey L. Van Hoosear }{ }^{111}
$$

109. See Alternatives to Marriage Project, AR Adoption Ban, http://www.unmarried. org/ar-adoption-ban.html (last visited Aug. 4, 2009) (providing the text of Arkansas Ballot Initiative No. 1 (passed in November 2008), which precludes same-sex couples from adopting or fostering children). The text of the initiative reads:

An act providing that an individual who is cohabitating outside of a valid marriage may not adopt or be a foster parent of a child less than eighteen years old ... [p]roviding that a minor may not be adopted or placed in a foster home if the individual seeking to adopt or to serve as a foster parent is cohabiting with a sexual partner outside of a marriage which is valid under the constitution and laws of this state; ... the foregoing prohibition applies equally to cohabiting opposite-sex and same-sex individuals.

Id. While the adoption law applies on its face to those cohabiting with either opposite-sex or same-sex partners, the law falls much harder on gay and lesbian couples, who have no ability to marry in Arkansas. See Lambda Legal, Lambda Legal's Safety Scale: Respect for Same-Sex Couples' Relationships, http://data.lambdalegal.org/publications/downloads/fs lambda-legals-safety-scale.pdf (last visited Aug. 4, 2009) (ranking states' constitutional treatment of same-sex couples and noting that, as of 2009 , the constitutions of twenty-five states, including Arkansas, ban marriage for same-sex couples).

110. Appendix of Exhibits in Support of Brief of Amici Curiae Individual Chapman University Organizations, Faculty, Staff, and Students, Orange County Equality Coalition, and Other Orange County Community Members Including Legally Married Same-Sex Couples, in Support of Petitioners at 3-4, Strauss v. Horton, 207 P.3d 48 (Cal. 2009) (No. 168047), available at http://www.courtinfo.ca.gov/courts/supreme/highprofile/documents/s 168047-amcur-chapman.pdf (providing the personal declaration of Karla Bland, a fortyone-year-old telecommunications worker and married lesbian).

111. Id. at 39 (providing the personal declaration of Jeffrey L. Van Hoosear, a fortyeight-year-old lawyer and married gay man). 
According to Lambda Legal's current "safety scale," twenty-five states' constitutions expressly bar same-sex couples from legal marriage recognition and do not otherwise provide legal protection for these couples. ${ }^{112}$ In addition, ten states and Puerto Rico have statutes or regulatory practices that bar marriage between same-sex couples and do not otherwise provide legal protections for these couples. ${ }^{13}$ One state recognizes outof-state marriages between same-sex couples, ${ }^{114}$ one state provides samesex couples similar protections to marriage under the label of civil union, ${ }^{115}$ and three other states, including California, have constitutionally barred same-sex couples from marriage but provide protections similar to marriage under a different label, such as "civil union."116 Finally, only six states have recognized and maintained marriage equality for same-sex couples and opposite-sex couples alike. ${ }^{117}$ Three of those states-Massachusetts, Connecticut, and Iowa-have afforded same-sex couples the right to marry through court decisions, as California did before the passage of Proposition 8 eliminated the right of same-sex couples to marry. ${ }^{118}$

112. Lambda Legal, Lambda Legal's Safety Scale: Respect for Same-Sex Couples' Relationships, http://data.lambdalegal.org/publications/downloads/fs_lambda-legals-safetyscale.pdf (last visited Aug. 4, 2009) (ranking states' constitutional treatment of same-sex couples). As of 2009, the constitutions of twenty-five states, half of the country, not only ban marriage for same-sex couples, but also either provide no protections for same-sex couples or contain provisions causing even more harm to same-sex couples: Alabama, Alaska, Arizona, Arkansas, Florida, Georgia, Idaho, Kansas, Kentucky, Louisiana, Michigan, Mississippi, Missouri, Montana, Nebraska, North Dakota, Ohio, Oklahoma, South Carolina, South Dakota, Tennessee, Texas, Utah, Virginia, and Wisconsin. Id.

113. Id. (listing ten states and Puerto Rico that ban marriage for same-sex couples and provide no legal protections for same-sex couples to mitigate the harm: Delaware, Illinois, Indiana, Minnesota, New Mexico, North Carolina, Pennsylvania, Rhode Island, West Virginia, and Wyoming).

114. Id. (noting that New York recognizes out-of-state marriages of same-sex couples).

115. Id. (stating that New Jersey affords same-sex couples the right to "civil unions," but not marriage).

116. Id. (noting that California, Oregon, and Washington have banned marriage but provide protections for same-sex couples under a different label).

117. Lambda Legal, Lambda Legal's Safety Scale: Respect for Same-Sex Couples' Relationships, http://data.lambdalegal.org/publications/downloads/fs_lambda-legals-safetyscale.pdf (last visited Aug. 4, 2009) (listing these states as Connecticut, Iowa, Maine, Massachusetts, New Hampshire, and Vermont).

118. In re Marriage Cases, 183 P.3d 384, 419 (Cal. 2008) (holding that the right of all Californians-including both same-sex and opposite-sex couples-to marry is fundamental), superseded in part by constitutional amendment, CAL. CONST. art. I, § 7.5, as recognized in Strauss v. Horton, 207 P.3d 48 (Cal. 2009); Kerrigan v. State Comm'r of Pub. Health, 957 A.2d 407, 481 (Conn. 2008) (requiring that same-sex couples be allowed to marry in Connecticut); Varnum v. Brien, 763 N.W.2d 862, 906-07 (Iowa 2009) (declaring unanimously that same-sex couples have the right to marry); Goodridge v. Dep't of Pub. 
In Goodridge v. Department of Public Health, the Supreme Court of Massachusetts became the first state high court to find marriage bans unconstitutional. ${ }^{119}$ That court held that denying marriage licenses to samesex couples violated the Massachusetts constitution on both equal protection and due process grounds. ${ }^{120}$ The court addressed both grounds simultaneously because "[i]n matters implicating marriage, family life, and the upbringing of children, the two constitutional concepts frequently overlap, as they do here." ${ }^{121}$ Finding that there was no need to consider the argument that this case warranted strict scrutiny, the court held that the law prohibiting same-sex couples from marrying did not pass muster even under the rational basis test. ${ }^{122}$

The State's three primary arguments in defense of limiting marriage to opposite-sex couples were to maintain prime circumstances for procreation, to maintain prime circumstances for child-rearing, and to preserve state resources by denying benefits to gays and lesbians, who, the State argued, are more financially independent. ${ }^{123}$ The court rejected all three interests as not having a rational relationship to the law barring marriages for same-sex couples. ${ }^{124}$ The court reasoned that marriage was not dependent on the ability or the desire to procreate, nor were state benefits from marriage dependent on the financial independence of an individual. ${ }^{125}$ In respect to the child-rearing argument, the majority held that Massachusetts courts had already deemed that the welfare of a child was not determined by the sexual orientation of the parents or the make-up of other families. ${ }^{126}$ And with no evidence to the contrary, the absence of

Health, 798 N.E.2d 941, 969-70 (Mass. 2003) (requiring that same-sex couples be allowed to marry in Massachusetts).

119. Goodridge, 798 N.E.2d at $969-70$.

120. Id.

121. Id. at 953 .

122. Id. at 961 (rejecting the State's arguments in support of barring same-sex couples from legally marrying). According to the court, "providing a "favorable setting for procreation," ensuring a two-parent (one of each sex) family unit as the "optimal setting for child rearing," and preserving financial resources are not legitimate legislative interests sufficient to overcome judicial scrutiny under the rational basis test. Id.

123. Id.

124. Goodridge, 798 N.E.2d at 961-64.

125. Id. at 961 (stating that Massachusetts's "laws of civil marriage do not privilege procreative heterosexual intercourse between married people above every other form of adult intimacy and every other means of creating a family").

126. Id. at 962-63 (explaining that demographics change, and there is no basis for determining that child welfare will be hurt by same-sex parents). The court emphasized that same-sex parents are often "excellent." Id. at 963. 
a civil marriage in a child's life could be harmful to the child by denying many tangible and intangible benefits attached to marriage. ${ }^{127}$

The court deconstructed the claim that lifting the ban on marriage between same-sex couples would obliterate traditional notions of marriage by explaining that, though permitting same-sex couples to marry would redefine marriage, the values and purpose of civil marriage would survive just as they had through past redefinitions to recognize the rights of women and interracial couples. ${ }^{128}$ Finally, addressing the argument that allowing same-sex couples to marry would cause interstate conflict, the court responded that "[t]he genius of our [f]ederal system is that each [s]tate's [c]onstitution has vitality specific to its own traditions, and that subject to the minimum requirements of the Fourteenth Amendment, each [s]tate is free to address difficult issues of individual liberty in the manner its own [c]onstitution demands." 129

Because the Massachusetts court found that the state's marriage ban could not withstand even rational basis review, it did not reach the question of whether sexual orientation is a suspect classification. ${ }^{130}$ Five years later, the California Supreme Court did reach that question. ${ }^{131}$

In its May 15, 2008 decision, the California Supreme Court invalidated Proposition 22-the statutory precursor to Proposition 8-which decreed that "only marriage between a man and a woman is valid and recognized in California." 132 That statute had been passed by a ballot initiative in California in 2000. ${ }^{133}$ The court found that gays and lesbians had a right to marry that was grounded in the fundamental right to marry that ap-

127. Id. at 964 ("Excluding same-sex couples from civil marriage will not make children of opposite-sex marriages more secure, but it does prevent children of same-sex couples from enjoying the immeasurable advantages that flow from the assurance of 'a stable family structure in which children will be reared, educated, and socialized.'"). The majority went on to address two other secondary arguments. Id. at 964-68 (striking down arguments that same-sex marriage would "trivialize or destroy the institution of marriage," that only the legislature might define the boundaries of marriage because of "the State's strong interest in the institution of marriage," and that expanding marriage rights would "lead to interstate conflict").

128. Id. at 958 (explaining the history of interracial marriage bans, comparing them to marriage bans affecting same-sex couples, and asserting that "history must yield to a more fully developed understanding of the invidious quality of the discrimination" (footnote omitted)).

129. Goodridge v. Dep't of Pub. Health, 798 N.E.2d 941, 967 (Mass. 2003).

130. See id. at 961.

131. In re Marriage Cases, 183 P.3d 384, 419 (Cal. 2008) (holding, among other things, that sexual orientation is a suspect classification for purposes of equal protection analysis), superseded in part by constitutional amendment, CAL. ConsT. art. I, \$ 7.5, as recognized in Strauss v. Horton, 207 P.3d 48 (Cal. 2009).

132. Id. at 409 (describing the limiting language of Proposition 22).

133. Id. 
plies to all persons under the California constitution. ${ }^{134}$ The court also found that sexual orientation is a "suspect classification" for equal protection purposes ${ }^{135}$ and held that there was no compelling state interest in limiting marriage to opposite-sex couples. ${ }^{136}$

Rather than the three-tiered model used in federal equal protection analysis, California utilizes a two-tiered model where suspect and quasisuspect classes are reviewed under strict scrutiny and all other laws are subject to rational basis review. ${ }^{137}$ The practical difference is that, while gender discrimination is given intermediate scrutiny, in the federal courts, California affords strict scrutiny analysis to gender-based discrimination as well as to discrimination based on race and religion. ${ }^{138}$ Finding similar patterns of discrimination faced by sexual orientation minorities as faced by other minority groups, the court found that sexual orientation met the qualifying criteria of a "suspect" classification because sexual orientation "bears no relation to a person's ability to perform or contribute to society, and is ... associated with a stigma of inferiority and second-class citizenship, manifested by the group's history of legal and social disabilities." 139

Importantly, although immutability and political powerlessness are also traditional factors to consider for suspect classification, the court pointed

134. Id. at 427. The court noted that:

In light of the fundamental nature of the substantive rights embodied in the right to marry - and their central importance to an individual's opportunity to live a happy, meaningful, and satisfying life as a full member of society-the California [c]onstitution properly must be interpreted to guarantee this basic civil right to all individuals and couples, without regard to their sexual orientation.

Id. (emphasis in original) (footnote omitted).

135. Id. at 441-42.

136. In re Marriage Cases, 183 P.3d at 451 ("After carefully evaluating the pertinent considerations in the present case, we conclude that the state interest in limiting the designation of marriage exclusively to opposite-sex couples, and in excluding same-sex couples from access to that designation, cannot properly be considered a compelling state interest for equal protection purposes.").

137. Id. at 401 . The court explained:

Although in most instances the deferential "rational basis" standard of review is applicable in determining whether different treatment accorded by a statutory provision violates the state equal protection clause, a more exacting and rigorous standard of review-"strict scrutiny"-is applied when the distinction drawn by a statute rests upon a so-called "suspect classification" or impinges upon a fundamental right.

Id. The court further explained that state equal protection analysis does not include an intermediate scrutiny, and strict scrutiny is used for both suspect and quasi-suspect classes in California. Id. at 444.

138. Id. at 444 ("Unlike decisions applying the federal [E]qual [P]rotection [C]lause, California cases continue to review, under strict scrutiny rather than intermediate scrutiny, those statutes that impose differential treatment on the basis of sex or gender.").

139. Id. at 442. 
out that neither is necessary to such a finding. ${ }^{140}$ The California Supreme Court specifically found that, like religion, "sexual orientation is so integral an aspect of one's identity, it is not appropriate to require a person to repudiate or change his or her sexual orientation in order to avoid discriminatory treatment." 141 Similarly, the court reasoned that current political powerlessness is not necessary; otherwise, "it would be impossible to justify the numerous decisions that continue to treat sex, race, and religion as suspect classifications." 142

The supreme court explicitly disagreed with the lower court's rejection of sexual orientation as a suspect classification based upon an immutability analysis. ${ }^{143}$ By finding immutability to be unnecessary and acknowledging the integral nature of sexual orientation to personhood, the court issued a decision profoundly respectful of gay men and lesbians that is straightforward in its analysis of the criteria for finding a classification "suspect." 144

Strict scrutiny was also applied in the Marriage Cases based on the principle that any law infringing upon a fundamental and constitutionally protected right is deserving of the most searching constitutional review. ${ }^{145}$ The court stated:

[T]he right to marry is a basic, constitutionally protected, civil right. . . . [O]ur cases make clear that the right to marry is ... protected by the privacy provision of article $I$, section 1 , and of the liberty interest protected by the due process clause of article I, section 7 [of the California constitution]. ${ }^{146}$

The court rejected the argument that the scope of the right to marry is limited to opposite-sex couples merely because marriage has historically been between a man and a woman and further explained that tradition has never been enough to justify the infringement of a fundamental

140. Id. at 443.

141. In re Marriage Cases, 183 P.3d 384, 442 (Cal. 2008), superseded in part by constitutional amendment, CAL. ConsT. art. I, § 7.5, as recognized in Strauss v. Horton, 207 P.3d 48 (Cal. 2009).

142. Id. at 443 (stating that California has never "identified a group's current political powerlessness as a necessary prerequisite for treatment as a suspect class" (emphasis in original)).

143. Id. at 442 ("We disagree . . with the Court of Appeal's conclusion that it is appropriate to reject sexual orientation as a suspect classification, in applying California's equal protection clause, on the ground that there is a question as to whether this characteristic is or is not 'immutable." ").

144. See id.

145. Id. at 443 .

146. In re Marriage Cases, 183 P.3d at 426 (emphasis in original) (explaining that marriage has been deemed a fundamental right by both the California Supreme Court and the United States Supreme Court). 
right. ${ }^{147}$ The court pointed to state precedents, ${ }^{148}$ such as Sail'er Inn $v$. Kirby, in which the California Supreme Court struck down a law prohibiting the hiring of female bartenders, ${ }^{149}$ and Perez $v$. Sharp, in which the same court struck down the California anti-miscegenation law rooted in the traditional idea that the right to marry was limited to intra-racial couples. ${ }^{150}$

In the Marriage Cases, the court held that Proposition 22 was unconstitutional on both due process and equal protection grounds under the California constitution because the State failed to meet its burden of demonstrating that Proposition 22 addressed a "compelling state interest."151 The court found "the interest in retaining the traditional and well-established definition of marriage" was not compelling because allowing same-sex couples to marry did not harm the existing concept of marriage. ${ }^{152}$ On the other hand, denying marriage equality significantly harms same-sex couples and their families. ${ }^{153}$ Also, addressing much controversy, the court held that "affording same-sex couples the opportunity to obtain the designation of marriage will not impinge upon the religious freedom of any religious organization, official, or any other person by requiring religious institutions to perform marriages for same-sex couples." 154

147. Id. at 452 (holding that "retention of the traditional definition of marriage does not constitute a state interest sufficiently compelling, under the strict scrutiny equal protection standard, to justify withholding that status from same-sex couples").

148. Id. at 427 (citing Sail'er Inn, Inc. v. Kirby, 485 P.2d 529, 543 (Cal. 1971); Perez v. Lippold, 198 P.2d 17, 26 (Cal. 1948)).

149. Sail'er Inn, 485 P.2d at 533 ("Although an inability to perform the tasks required by a particular occupation, sex-linked or not, may be a justification for discrimination against job applicants, ... mere prejudice, however ancient, common or socially acceptable, is not.").

150. Perez, 198 P.2d at 29 (invalidating California anti-miscegenation law). Rejecting the State's arguments in favor of the law, the court stated:

Respondent maintains that Negroes are socially inferior and have so been judicially recognized ... and that the progeny of a marriage between a Negro and a Caucasian suffer not only the stigma of such inferiority but the fear of rejection by members of both races. If they do, the fault lies not with their parents, but with the prejudices in the community and the laws that perpetuate those prejudices by giving legal force to the belief that certain races are inferior.

Id. at 26 (citation omitted).

151. In re Marriage Cases, 183 P.3d at 401.

152. Id.

153. Id. ("While retention of the limitation of marriage to opposite-sex couples is not needed to preserve the rights and benefits of opposite-sex couples, the exclusion of samesex couples from the designation of marriage works a real and appreciable harm upon same-sex couples and their children.").

154. Id. at 451 (addressing concerns by religious groups that permitting same-sex couples to enter into legal civil marriages would unduly burden the various religious defini- 
Shortly after the California decision, the Supreme Court of Connecticut, in Kerrigan v. Commissioner of Public Health, similarly held that barring marriages between same-sex couples was unconstitutional because it violated the Connecticut constitution's equal protection provisions. ${ }^{155}$ In that case, the court modeled its equal protection analysis after that of the federal courts and held that gays and lesbians are a quasi-suspect class satisfying four factors articulated by the United States Supreme Court for determining suspect classifications. ${ }^{156}$ Those factors include two requirements: (1) that "the group has suffered a history of invidious discrimination", ${ }^{157}$ and (2) "the characteristics that distinguish the group's members bear 'no relation to their ability to perform or contribute to society'",158 along with two subsidiary considerations: (1) whether the characteristic that defines the group's members as a discrete group is "immutable" or otherwise beyond members' control:;59 and (2) whether the group is " 'a minority or politically powerless.'" $" 160$

tions of marriage). The court attempted to reassure these groups that "no religion will be required to change its religious policies or practices with regard to same-sex couples, and no religious officiant will be required to solemnize a marriage in contravention of his or her religious beliefs." Id. at 451-52.

155. Kerrigan v. Comm'r of Pub. Health, 957 A.2d 407, 482 (Conn. 2008).

156. Id. at 425-26. But the court noted that the United States Supreme Court had only recognized gender and illegitimacy as "quasi-suspect" classifications. Id. at 426 .

157. Id. at 426 (citing United States v. Virginia (VMI), 518 U.S. 515, 531-32 (1996); Massachusetts Bd. of Ret. v. Murgia, 427 U.S. 307, 313 (1976) (explaining that elderly people have faced a history of discrimination)).

158. Id. (quoting Frontiero v. Richardson, 411 U.S. 677,686 (1973)).

159. Id. (citing Lyng v. Castillo, 477 U.S. 635,638 (1986)). The Connecticut court also noted that, even though immutability is a factor, it is not determinative of quasi-suspect status because the United States has granted this status even when non-immutable traits are at issue. Id. at 429 n.20. The court stated that:

[F]or purposes of determining whether a group is entitled to suspect or quasi-suspect class status-and, in contrast to the considerations of historical discrimination and whether the group's distinguishing characteristic bears on the ability of its members to participate in and contribute to society-"immutability is not a requirement, but a factor."

Id. (quoting Janet E. Halley, Sexual Orientation and the Politics of Biology: A Critique of the Argument from Immutability, 46 STAN. L. REv. 503, 507 (1994)).

160. Kerrigan, 957 A.2d at 426 (quoting Bowen v. Gilliard, 483 U.S. 587, 602 (1987)). The court considered immutability and political powerlessness to be relevant, though not dispositive. $I d$. at 429 . As the majority put it:

Because the court has identified the immutability of the group's distinguishing characteristic and the group's minority status or relative lack of political power as potentially relevant factors to the determination of whether heightened judicial protection is appropriate, we, too, shall consider those factors for purposes of our inquiry under the state constitution.

Id. 
The Connecticut court noted that immutability "has been deemed to be a relevant consideration because it 'make[s] discrimination more clearly unfair" "161 and acknowledged that, while a number of courts had rejected the claim that sexual orientation is "immutable," other courts and many scholarly commentators had reached the opposite conclusion. ${ }^{162}$ The Supreme Court of Connecticut stated: "Although we do not doubt that sexual orientation-heterosexual or homosexual-is highly resistant to change, it is not necessary for us to decide whether sexual orientation is immutable in the same way and to the same extent that race, national origin and gender are immutable because, even if it is not, the plaintiffs nonetheless have established that they fully satisfy this consideration."163

The court went on to cite prior cases describing the importance of sexual intimacy and the significance of sexual orientation to personal identity. ${ }^{164}$ Specifically citing to the Marriage Cases, the majority concluded: "It is apparent that, '[b]ecause a person's sexual orientation is so integral an aspect of one's identity, it is not appropriate to require a person to repudiate or change his or her sexual orientation to avoid discriminatory treatment." "165

Thus, the court found that, given sexual orientation's central role in the right to self-determination, it was the kind of "distinguishing characteristic" defining the plaintiffs as a group that should be afforded heightened protection under an equal protection analysis. ${ }^{166}$ Relying on prior cases, the court found that it would be "abhorrent" to penalize a person for not changing a characteristic that could only be changed at the expense of "significant damage" to self-identity. ${ }^{167}$

The court also rejected the argument that Romer $v$. Evans precluded application of heightened scrutiny, explaining that, in Romer, the Supreme Court had no reason to apply heightened scrutiny when the

161. Id. at 436 (quoting High Tech Gays v. Def. Indus. Sec. Clearance Office, 909 F.2d 375, 377 (9th Cir. 1990) (Canby, J., dissenting)).

162. Id. at 436-37.

163. Id. at 437.

164. Id. at 437-38 ("[T] he United States Supreme Court has recognized that, because 'the protected right of homosexual adults to engage in intimate, consensual conduct ... [represents] an integral part of human freedom.'" (quoting Lawrence v. Texas, 539 U.S. 558, 576-77 (2003)).

165. Kerrigan v. Comm'r of Pub. Health, 957 A.2d 407, 438 (Conn. 2008) (quoting In re Marriage Cases, 183 P.3d 384, 442 (Cal. 2008), superseded in part by constitutional amendment, CAL. Const. art. I, \$ 7.5, as recognized in Strauss v. Horton, 207 P.3d 48 (Cal. 2009)).

166. Id.

167. Id. at $438-39$. 
amendment at issue could not even survive the rational basis test. ${ }^{168}$ Further, the court stated that when Lawrence overruled Bowers, the United States Supreme Court established that moral disapproval alone was an insufficient basis to justify discrimination, actually opening the door for the states to provide heightened protection for gay and lesbian people. ${ }^{169}$ In Kerrigan, the court found that sexual orientation is a quasi-suspect classification requiring intermediate scrutiny, and the State was not able to demonstrate that the marriage limitation was "substantially related to an important governmental interest." 170

While the Connecticut court analyzed "immutability" much like the California Supreme Court did, it did not conclude, like California, that a finding of immutability was "unnecessary."171 Rather, it held that the immutability factor was "satisfied."172 In essence, the Connecticut Supreme Court, like California's, found that immutability was not required to invoke heightened scrutiny, but still found that it was a relevant "factor" that was met in the Kerrigan case. ${ }^{173}$ What was "satisfied," however, was something short of "immutability" in the strict sense. Accordingly, the court seemed to conclude that the centrality of sexual orientation to personhood is "close enough" to a finding of immutability.

The Iowa Supreme Court took a similar path. ${ }^{174}$ Like Connecticut, it also invalidated a marriage limitation on the basis that a ban violated the Equal Protection Clause under intermediate scrutiny analysis. ${ }^{175}$ The Iowa court's decision in Varnum $v$. Brien was unanimous. ${ }^{176}$ Like the

168. Id. at 468 ("Because the [C]ourt indicated that the Colorado constitutional amendment could not withstand even rational basis review, the lowest level of judicial scrutiny, the [C]ourt had no reason to decide whether heightened review was appropriate." (citing Romer v. Evans, 517 U.S. 620, 624 (1996))).

169. Id. at 467 (explaining that, by considering the Texas statute at issue in Lawrence v. Texas in terms of due process rather than equal protection, the Supreme Court highlighted the fact that homosexuals were entitled to the same right to privacy as heterosexuals). The Kerrigan court stated, "Lawrence represents a sea change in United States Supreme Court jurisprudence concerning the rights of gay persons.... In stark contrast to Bowers, Lawrence recognizes that gay persons, no less than heterosexuals, are constitutionally entitled to freedom from state interference in matters of sexual intimacy." Id.

170. Kerrigan, 957 A.2d at 481.

171. See id. at 438.

172. $I d$.

173. Id.

174. Varnum v. Brien, 763 N.W.2d 862, 904 (Iowa 2009) (invalidating Iowa's marriage law permitting marriage only between opposite-sex couples under intermediate scrutiny analysis).

175. Id. (concluding that, after application of intermediate scrutiny to Iowa's law banning marriage for same-sex couples, the sexual-orientation classification furthered no important governmental objectives).

176. Id. at 907 . 
Connecticut Supreme Court, the Iowa court analyzed the traditional "immutability" factor of sexual orientation and agreed with other courts that this factor was satisfied because of sexual orientation's centrality to identity. ${ }^{177}$

The court stated that gays and lesbians were situated similarly to heterosexuals under the civil marriage statute because gay and lesbian couples are also "in committed and loving relationships, many raising families," and concluded that "official recognition of their status provides an institutional basis for defining their fundamental relational rights and responsibilities." 178 The court rejected claims that the marriage statute did not classify based upon sexual orientation, arguing that offering gays and lesbians the right to marry only someone of the opposite sex is "no right at all."179

Because the court found that the Iowa statute failed intermediate scrutiny, it was unnecessary to examine the applicability of strict scrutiny to that case. ${ }^{180}$ The State was unable to provide any justification for the statute that could survive intermediate scrutiny, ${ }^{181}$ which requires that the statute be "substantially related to an important governmental objective." 182

Significantly, despite overwhelming evidence of systematic discrimination against gays and lesbians, the California Supreme Court was the first

177. Id. at 893 (noting that "[t] he constitutional relevance of the immutability factor is not reserved to those instances in which the trait defining the burdened class is absolutely impossible to change" and adopting the reasoning that sexual identity is integral to one's identity). Like Kerrigan, this court held that gays and lesbians satisfied the four considerations that invoke heightened scrutiny: history of invidious discrimination, ability to contribute to society, immutability, and political powerlessness. Id. at 889-96. The court explained that there is overwhelming evidence that gays and lesbians have historically been the targets of discrimination, and it is well-established and accepted that sexual orientation is not relevant to one's ability to contribute to society. Id. at 889-92. The court went on to articulate that sexual orientation is immutable because it is so much at the core of one's identity that it would be unthinkable to require an individual to change it, assuming change were even possible. Id at $892-93$. Finally, the court described the lack of marriage equality and ongoing challenges as indications that gays and lesbians are politically powerless in the context of equal protection. Id. at 895 .

178. Id. at 883.

179. Varnum, 763 N.W.2d at 885 ("Viewed in the complete context of marriage, including intimacy, civil marriage with a person of the opposite sex is as unappealing to a gay or lesbian person as civil marriage with a person of the same sex is to a heterosexual.").

180. Id. at 896 .

181. Id. at 897-904 (explaining that the State offered five objectives: (1) protecting "the traditional notion of marriage"; (2) promoting an optimal environment to raise children; (3) promoting procreation; (4) "promoting stability in opposite sex relationships"; and (5) conserving resources, none of which qualified as important governmental interests sufficient to withstand heightened scrutiny).

182. Id. at 896-97 (quoting Clark v. Jeter, 486 U.S. 456, 461 (1988)). 
state supreme court to explicitly hold that sexual orientation is a "suspect classification" for equal protection purposes. ${ }^{183}$ Other states that have concluded that gays and lesbians have a right to marry have done so without making this finding. ${ }^{184}$ Massachusetts found that limiting marriage to opposite-sex couples failed even rational basis review, obviating the need to decide whether gays and lesbians fall under a suspect classification. ${ }^{185}$ Connecticut's supreme court found that gays and lesbians are entitled to intermediate scrutiny, ${ }^{186}$ as did the Supreme Court of Iowa. ${ }^{187}$ The federal courts have never explicitly extended to gays and lesbians the protections of strict scrutiny or even intermediate scrutiny. ${ }^{188}$ Thus, while the Fourteenth Amendment guarantees equal protection, the federal courts have never fully protected LGBTs under that provision.

\section{Proposition 8 and the Peculiar Vulnerability of LGBTs}

"A few weeks after our wonderful and amazing two-day wedding I was driving home from work, got off the freeway... and there they were. I had seen the signs, but I guess I did not expect to see the [protestors supporting Proposition 8]. My heart began to beat furiously. I glared intently at one woman from my car window and I swear she actually looked down. Perhaps this is a projection, but I sensed that she saw me, my face, my eyes, my pain, and she felt ashamed. There were a lot of them, more than 50. But then, as I approached the median ... there was one young woman, very small, with dark hair, standing there, surrounded by the pasty-faced yellowshirted glossy-eyed fancy-printed-sign holders, with a homemade sign on a piece of cardboard that simply said 'No on 8.' I screamed out my car window that I'd be right there. By the time I parked, a small man with head of

183. See In re Marriage Cases, 183 P.3d 384, 441-42 (Cal. 2008), superseded in part by constitutional amendment, CAL. ConsT. art. I, § 7.5, as recognized in Strauss v. Horton, 207 P.3d 48 (Cal. 2009).

184. E.g., Kerrigan v. Comm'r of Pub. Health, 957 A.2d 407, 430-32 (Conn. 2008); Varnum, 763 N.W.2d at 896-97; Goodridge v. Dep't of Pub. Health, 798 N.E.2d 941, 961 (Mass. 2003).

185. Goodridge, 798 N.E.2d at 961.

186. Kerrigan, 957 A.2d at $430-32$.

187. Varnum, 763 N.W.2d at 896-97.

188. Jeremy B. Smith, Note, The Flaws of Rational Basis with Bite: Why the Supreme Court Should Acknowledge Its Application of Heightened Scrutiny to Classifications Based on Sexual Orientation, 73 Fordham L. Rev. 2769, 2770 (2005). As Smith points out:

Traditionally, only a few classifications have merited heightened scrutiny - most notably gender and race classifications. Despite their ostensible qualification for heightened scrutiny based on criteria set forth by the U.S. Supreme Court, gay men and lesbians have not yet been treated as a suspect class and thus classifications based on sexual orientation have been historically subject to rational basis review.

Id. (footnotes omitted). 
curly reddish brown hair had arrived carrying a bunch of no on 8 signs. He did not know who I was, but he handed me a sign. Another night, at the same street corner, I remember asking him 'Harvey, why are you here, why are you doing this?' And without a beat he answered 'I am trying to save my life." "

-Laura Kanter ${ }^{189}$

On November 4, 2008, the voters of California became the first to strip vested marriage rights away from members of a judicially protected minority group. ${ }^{190}$ For several months prior to the passage of the proposition, gays and lesbians enjoyed the right to marry alongside their straight counterparts. ${ }^{191}$ Thus far in other states, when majorities have passed laws defining marriage as being only "between a man and a woman," voters did so before same sex couples were actually allowed to marry in those states. ${ }^{192}$ In Florida and Arizona, for example, where voters passed constitutional amendments similar to California's, the voters did so as a "pre-emptive strike"; the courts in those states had not yet recognized that same-sex couples had a right to marry. ${ }^{193}$ Perhaps because California has often been in the vanguard of social progress, the battle over Proposition 8 raged far beyond the state's borders. ${ }^{194}$ Proposition 8 was an attempt to repudiate the California Supreme Court's decision recognizing the fundamental equality of gays and lesbians and to enshrine in California's state constitution the limitation on marriage contained in the earlier (and now-invalidated) statute. Proposition 8 was supported by fifty-two

189. My Eve of Justice Speech, http://lauraflaps.blogspot.com/2009/03/my-eve-of-justice-speech.html (Mar. 16, 2009, 23:11 PST).

190. Jesse McKinley \& Laurie Goodstein, Bans in 3 States on Gay Marriage, N.Y. Times, Nov. 5, 2008, at A1, available at 2008 WLNR 21173920 (stating that Proposition 8, which superseded the Marriage Cases by amending the California constitution to prohibit marriage between same-sex couples, passed in California on November 4, 2008).

191. Id. ("In California, where same-sex marriage had been performed since June, the ban had more than 52 percent of the vote, according to figures by the secretary of state, and was projected to win by several Californian news media outlets.").

192. Id. (stating that in Arizona, where marriage between same-sex couples was already banned, citizens voted to continue to prohibit such marriages).

193. Marcus Baram, Gay Marriage Bans Succeeding, The Huffington Post, Nov. 5 , 2008, http://www.huffingtonpost.com/2008/11/05/gay-marriage-bans-succeed_n_141286. $\mathrm{html}$ (stating that Florida, which amended its constitution in 2008 to preclude marriage equality, had already banned marriage between same-sex couples since 1997); Jesse McKinley \& Laurie Goodstein, Bans in 3 States on Gay Marriage, N.Y. Times, Nov. 5, 2008, at A1, available at 2008 WLNR 21173920 ("In Arizona, where same-sex marriage was already against the law, the victory for Proposition 102, which amends the [s]tate [c]onstitution, was met with a shrug by some.").

194. Cf. Join the Impact, Prop 8 Remains-What's Next?, http://jointheimpact.com/ tag/prop-8/ (last visited July 18, 2009) (detailing efforts to organize marriage equality supporters to prevent amendments like Proposition 8 from passing in other states). 
percent of California voters ${ }^{195}$ and was recently upheld by the California Supreme Court, which analyzed the peculiar system by which Californians can amend their state constitution. ${ }^{196}$ Focusing on the fact that Proposition 8 did not constitute a fundamental change to the structure of state government, the court rejected the argument that Proposition 8 was an invalid "revision" of the state constitution, as opposed to a valid "amendment." 197

Proposition 8 , however, plainly and explicitly deprives gay and lesbian citizens of marriage rights, ${ }^{198}$ though marriage has already been recognized as a "fundamental right" by the California Supreme Court. ${ }^{199}$ Moreover, under California law, Proposition 8 denies a fundamental right to a group of persons whose minority classification (sexual orientation) has been deemed "suspect" by the state's highest court. ${ }^{200}$ That made Proposition 8 unlike prior initiatives that the courts upheld based upon the sanctity of voter initiative. ${ }^{201}$

195. Jesse McKinley \& Laurie Goodstein, Bans in 3 States on Gay Marriage, N.Y. Times, Nov. 5, 2008, at A1, available at 2008 WLNR 21173920.

196. Strauss v. Horton, 207 P.3d 48, 110 (Cal. 2009).

197. See id.

198. Id. at 59 ("Proposition 8 ... added a new section [to] the California constitution, providing: "Only marriage between a man and a woman is valid or recognized in California."”).

199. In re Marriage Cases, 183 P.3d 384, 426 (Cal. 2008) (concluding that marriage is a fundamental personal right), superseded in part by constitutional amendment, CAL. ConsT. art. I, § 7.5, as recognized in Strauss v. Horton, 207 P.3d 48 (Cal. 2009). The court also noted that it is a flaw to describe the right to marry as the right to "same-sex marriage." Id. at 421 .

200. See id. The California Supreme Court held that marriage is a fundamental right for all people, including same-sex couples. Id. Moreover, the court in Marriage Cases explained that:

The flaw in characterizing the constitutional right at issue as the right to same-sex marriage rather than the right to marry goes beyond mere semantics. It is important both analytically and from the standpoint of fairness to adopt plaintiffs' argument that we recognize that they are not seeking to create a new constitutional right-the right to "same-sex marriage"- or to change, modify, or ... "deinstitutionalize" the existing institution of marriage. Instead, plaintiffs contend that, properly interpreted, the state constitutional right to marry affords to same-sex couples the same rights and benefits-accompanied by the same mutual responsibilities and obligations-as this constitutional right affords to same sex couples. For this reason, in evaluating the constitutional issue before us, we consider it appropriate to direct our focus to the meaning and substance of the constitutional right to marry, and to avoid the potentially misleading implications inherent in analyzing the issue in terms of "same-sex marriage."

Id. at 421 (footnote omitted).

201. See, e.g., People v. Frierson, 25 Cal.3d 142, 186 (1979) (upholding voter initiative that reinstated the death penalty after an earlier finding by the California Supreme Court that the death penalty was unconstitutional). 
Nevertheless, on May 26, 2009, the California Supreme Court upheld Proposition 8 as a proper amendment to the California constitution in Strauss $v$. Horton, which set the precedent that a bare majority vote can, in fact, strip constitutional rights from a suspect class. ${ }^{202}$ But the court also held that the approximately eighteen thousand marriages between same-sex couples would remain valid because Proposition 8 cannot be applied retroactively. ${ }^{203}$

The court articulated two factors as the basis for its decision. ${ }^{204}$ One was the "meaning and scope of the constitutional change at issue."205 The court reasoned that the "meaning and scope" of Proposition 8 was to limit the use and official recognition of the word "marriage" to oppositesex couples. ${ }^{206}$ The other factor was the "quantitative and qualitative effect" that the constitutional change would "have on the basic governmental plan or framework embodied in the preexisting provision of the California constitution."207 The quantitative aspect was quickly dismissed as evidence of an amendment, since Proposition 8 was short and simple. ${ }^{208}$

In its discussion of the qualitative effect, the court found that Proposition 8 was not a revision to the state constitution, despite the fact that Proposition 8 eliminated rights recognized in the Marriage Cases. ${ }^{209}$ The

202. Strauss, 207 P.3d at 62.

203. Id. (noting presumption against retroactive application and finding that language in voter information material was "insufficient to demonstrate, clearly and unambiguously, that the voters must have intended a retroactive application" (emphasis in original)).

204. Id. at 61 .

205. $I d$.

206. Id. at 69 (deconstructing the opinion in the Marriage Cases and parsing out the right to the word and institution of "marriage" from the general rights to privacy, due process, and equal protection).

207. Strauss, 207 P.3d at 69 .

208. Id. at 69 ("Quantitatively, Proposition 8 unquestionably has much less of an effect on the preexisting state constitutional scheme than virtually any of the previous constitutional changes that our past decisions have found to constitute amendments rather than revisions.").

209. Id. at 100 (holding that the Marriage Cases "did not make a qualitative revision"). The court explained:

[I]nitiative measures that, like the current Proposition 8 , cut back on the greater level of protection afforded by preceding court decisions and were challenged as constitutional revisions on the ground that the constitutional changes they effected deprived individuals of important state constitutional protections they previously enjoyed and left courts unable to fully protect such rights. Nonetheless, in each case this court did not undertake an evaluation of the relative importance of the constitutional right at issue or the degree to which the protection of that right had been diminished, but instead held that the measure did not amount to a qualitative revision because it did not make a fundamental change in the nature of the governmental plan or framework established by the [c]onstitution. 
majority explained that because gays and lesbians maintain the familial recognition and protections of domestic partnerships post-Proposition 8 , the rights of privacy, due process, and equal protection remain intact and effective. ${ }^{210}$ The court further explained that Proposition 8 merely carves out an exception-marriage-to those core constitutional principles and noted that rights are subject to change through California's initiative process. $^{211}$

While explicitly stating that it was not suggesting that the rights affected by Proposition 8 were "unimportant or insignificant," the court went on to note that the California amendment process "never has been reserved only for minor or unimportant changes to the [c]onstitution."212 In essence, the court found that significant changes, even those affecting the fundamental rights of a suspect classification, can be brought about by majority will in California. ${ }^{213}$

Proposition 8 powerfully demonstrates the peculiarly vulnerable position of LGBTs. ${ }^{214}$ A voter initiative aimed at a minority group that was explicitly protected by "suspect classification" status under the federal Constitution would likely be rejected as unconstitutional, as illustrated in the case of Mulkey v. Reitman, in which the California Supreme Court invalidated an initiative amendment on the grounds that it violated the Fourteenth Amendment of the United States Constitution. ${ }^{215}$ That initiative was aimed at denying African-American citizens the benefits of nondiscrimination. ${ }^{216}$ Because race is a "suspect classification" for federal

Id.

210. Id. at $75-76$.

211. Id. As the court stated, Proposition 8 "must be understood as carving out an exception to the preexisting scope of the privacy and due process clauses with respect to the particular subject matter encompassed by new provision." Id. at 75.

212. Strauss v. Horton, 207 P.3d 48, 102 (Cal. 2009) (emphasis in original).

213. See id. at 129 (Moreno, J., dissenting).

The rule the majority crafts today not only allows same-sex couples to be stripped of the right to marry that this court recognized in the Marriage Cases, it places at risk the state constitutional rights of all disfavored minorities. It weakens the status of our state [c]onstitution as a bulwark of fundamental rights for minorities protected from the will of the majority.

Id. A full consideration of Justice Moreno's powerful dissenting opinion is beyond the scope of this Article.

214. See Ronald Steiner, Understanding the Prop 8 Litigation: The Scope of Direct Democracy and Role of Judicial Scrutiny, 14 NExus 81, 86 (2009) (explaining that LGBTs are particularly vulnerable in states that have initiative systems because of the majoritarian nature of the process); cf. Strauss, 207 P.3d at 129 (Moreno, J., dissenting) (noting that all "disfavored minorities" are at risk after majority decision upholding Proposition 8).

215. Mulkey v. Reitman, 413 P.2d 825, 892 (Cal. 1966), aff'd, Reitman v. Mulkey, 387 U.S. 369, 381 (1967).

216. Reitman, 387 U.S. at 372. 
equal protection purposes, the court found that African-Americans' rights are immune from attack by a state majority. ${ }^{217}$

LGBTs do not have similar protections in the federal judicial system. ${ }^{218}$ The failure of the United States Supreme Court to designate sexual orientation a "suspect classification" leaves LGBTs' rights open to further assault beyond Proposition $8 .^{219}$

Even in relatively progressive California, sexual orientation discrimination has led to the commission of hate crimes. ${ }^{220}$ Indeed, the California Department of Justice's "Hate Crime in California 2007" statistical report ${ }^{221}$ notes that reported "sexual orientation hate crimes have consistently been the second largest bias motivation of hate crimes since 1998, accounting for at least 18 percent of all hate crime offenses."222 Moreover, reported hate crimes against the LGBT community increased $77.2 \%$ between 2006 and 2007. ${ }^{223}$ More recently, Santa Clara County in California has reported a threefold increase in hate crimes against LGBT people from 2007 to 2008 , which the prosecutor of that county attributes to the controversy surrounding Proposition $8 .^{224}$

In 1986, gay and black civil rights activist Bayard Rustin noted that "twenty-five years ago, the barometer of human rights in the United States [was] [B]lack people. That is no longer true. The barometer for judging the character of people in regard to human rights is now those who consider themselves gay, homosexual, lesbian."225 Documented evi-

217. Id. at 373 (ruling that an initiative that authorized discrimination in the housing market was unconstitutional because it violated a fundamental right without serving a compelling state interest).

218. See Jeremy B. Smith, Note, The Flaws of Rational Basis with Bite: Why the Supreme Court Should Acknowledge Its Application of Heightened Scrutiny to Classifications Based on Sexual Orientation, 73 Fordham L. Rev. 2769, 2770 (2005). For a fuller discussion of this point, see Part II of this Article.

219. See id. (stating that the Supreme Court has not given LGBTs the status of "suspect classification").

220. Criminal Justice Statistics Center, California Department of Justice, Hate Crime in California 20073 (2008), http://ag.ca.gov/cjsc/publications/hatecrimes/ hc07/preface07.pdf.

221. Id. at 1.

222. Id.

223. Id. at 7 ("Anti-homosexual hate crimes increased 77.2 percent from 57 in 2006 to 101 in 2007.").

224. Tracy Kaplan, Surge in Anti-Gay Hate Crime Cases, San Jose Mercury News, Mar. 16, 2009, available at http://www.topix.com/forum/county/santa-clara-ca/TSQN3R5EL NBKFEPTF ("Hate crime cases involving anti-gay sentiment shot up in Santa Clara County last year, a striking increase that a leading prosecutor attributes to controversy over Proposition 8, the voter-approved ban on gay marriage."). 2003).

225. Brother Outsider: The Life of Bayard Rustin (PBS television broadcast Jan. 20, 
dence unfortunately shows the extent to which gays and lesbians are still singled out for persecution and abuse. ${ }^{226}$

\section{Moving Beyond Proposition 8}

In Romer, the United States Supreme Court invalidated Colorado's Amendment 2 without having to reach the question of whether sexual orientation qualifies as a "suspect" classification. ${ }^{227}$ Given the extreme nature of the amendment at issue, the Court found that the amendment was motivated by "animus" and was, thus, precluded by the Equal Protection Clause, even when evaluated under the relatively forgiving rational basis test. ${ }^{228}$ It is unlikely, at this point at least, that the Supreme Court would invalidate Proposition 8 on such a basis. Rather, the Court might well accept a "rational basis" for upholding "traditional" marriage, ${ }^{229}$ despite the fact that animus underlies the motivations of many who voted to support Proposition $8 .^{230}$

The official campaign for Proposition 8 was sophisticated, avoiding a direct appeal to "animus." 231 The campaign was "kinder and gentler," in Eskridge's words, than past campaigns, ${ }^{232}$ with relatively benign ads portraying well-meaning neighbors of gays who proclaimed a belief in rights for gays and yet a concomitant belief that the term "marriage" should be preserved for unions between men and women. ${ }^{233}$ Thus, the argument

226. Criminal Justice Statistics Center, California Department of Justice, Hate Crime in CALIFORnia 20073 (2008), http://ag.ca.gov/cjsc/publications/hatecrimes/hc 07/preface07.pdf.

227. Romer v. Evans, 517 U.S. 620, 635 (1996).

228. Id. at 632 .

229. See Lawrence v. Texas, 539 U.S. 558, 585 (2003) (O'Connor, J., concurring) (suggesting that preserving the "traditional institution of marriage" is a legitimate state interest).

230. See William N. Eskridge, Jr., How Government Unintentionally Influences Culture (The Case of Same-Sex Marriage), 102 Nw. U. L. Rev. 495, 496 (2008) (noting that "religious persons opposing same-sex marriage often find their most enthusiastic audience consists of bigots and homophobes"). Professor Eskridge points out that the tendency to "demonize" marriage equality is counterproductive: "Probe more deeply, and the effect is even more disturbing. Demonizing gay marriage as the great threat to traditional marriage not only scapegoats gay people, but deflects attention away from genuine threats to the institution, including high divorce rates, deadbeat dads, domestic violence, and so on." Id.

231. See Protect Marriage - Yes on 8, http://www.protectmarriage.com/ (last visited Aug. 6, 2009) (campaigning for passage of Proposition 8).

232. See William Eskridge, Professor of Jurisprudence, Yale Law School, Remarks at the "Democracy's Dilemma: The Case of Proposition 8" AALS Executive Committee Roundtable, American Association of Law Schools Annual Meeting (Jan. 9, 2009).

233. See Protect Marriage - Yes on 8, http://www.protectmarriage.com/ (last visited Aug. 6, 2009) (containing information provided by the "Yes on 8 " campaign). 
that Proposition 8 was not motivated by animus alone would, at least, be easier to sustain than the arguments for Colorado's Amendment 2.234

It also seems unlikely that the Supreme Court would frame the issue as the California Supreme Court did, asking whether same-sex couples have a fundamental right to marry, rather than whether there exists a fundamental right to "same-sex marriage." 235 Just as the Lawrence Court focused on the right to intimate privacy in setting aside an anti-sodomy law, the California Supreme Court focused on the right to marriage, not the right to "same-sex marriage." 236 It is all too common, however, for the right to be defined by the group "targeted by the law."237 This "collapsible error," as Professor Rush describes it, or a tendency to narrow the description of the right so that only the disfavored minority is seeking it, is epitomized by Justice Scalia's dissent in Lawrence, in which he framed the issue as the right to engage in "homosexual sodomy."238 The California Supreme Court, in its 2008 Marriage Cases decision, correctly recognized that the right being sought by same-sex couples was simply the right to marry the persons of their choice, a right shared by all citizens. ${ }^{239}$ While the Supreme Court framed the issue of anti-sodomy laws in a similar way in Lawrence, ${ }^{240}$ it is considerably less clear that the Court would do so in the marriage context.

If the federal courts are not as likely to recognize marriage in terms of a broad fundamental right, exclusion from which must be justified under "strict scrutiny" analysis, then the other avenue for LGBTs to attain constitutional protection is to seek recognition of sexual orientation as a

234. See Romer v. Evans, 517 U.S. 620, 635 (1996) (noting that Colorado's stated rationale for Amendment 2 was to protect the rights of employers and landlords who might object to homosexuality itself).

235. In re Marriage Cases, 183 P.3d 384, 419 (Cal. 2008) ("Although our state [c]onstitution does not contain any explicit reference to a right to marry, past California cases establish beyond question that the right to marry is a fundamental right whose protection is guaranteed to all persons by the California [c]onstitution." (citations omitted)), superseded in part by constitutional amendment, CAL. ConsT. art. I, § 7.5, as recognized in Strauss v. Horton, 207 P.3d 48 (Cal. 2009).

236. Id. at 421.

237. Sharon E. Rush, Whither Sexual Orientation Analysis? The Proper Methodology When Due Process and Equal Protection Intersect, 16 WM. \& MARY BiLl RTs. J. 685, 743 (2008) (arguing that courts should avoid "committing the Collapsible Error, which happens when the underlying right is defined by the group targeted by the law" (footnote omitted))

238. Lawrence v. Texas, 539 U.S. 558, 586 (2003) (Scalia, J., dissenting) (focusing on the right to homosexual sodomy rather than the majority's broader focus on the right to privacy).

239. In re Marriage Cases, 183 P.3d at 426.

240. See Lawrence, 539 U.S. at 564 (framing the constitutional issue as whether consenting adults had a right to privately engage in sexual conduct that was burdened by the state's anti-sodomy law). 
"suspect" classification. ${ }^{241}$ While the Court has never done this, Justice O'Connor's concurring opinion in Lawrence, suggesting that Romer had, in fact, applied a more searching version of rational basis review for sexual orientation-based discrimination, might presage the willingness of the Court to recognize that LGBTs are entitled to heightened scrutiny under the Court's jurisprudence. ${ }^{242}$ That LGBTs have suffered from discrimination and that sexual orientation is unrelated to the ability to work or participate in society is well-established. ${ }^{243}$

Historically, courts have also referred to immutability as a "necessary prerequisite to suspect classification." 244 The California Supreme Court decision, which did not rely on a finding of immutability of sexual orientation, is significant because it "highlights the court's changing understandings of immutability and suspect classifications."245 Importantly, despite the fact that the court later upheld the passage of Proposition 8, its earlier finding that sexual orientation is a suspect classification is undisturbed, ${ }^{246}$ and this finding and its underlying rationale provide kernels of hope for further development of rights jurisprudence for LGBTs.

The description of sexual orientation as "integral," rather than "immutable," may provide a workable framework for further development of equal protection doctrine with regard to LGBTs, even in the federal

241. Of course, even gaining this status would not guarantee marriage equality, as courts might yet find that there is a "compelling state interest" in preserving the "traditional" definition of marriage. Preservation of traditional marriage would be far more difficult under strict scrutiny than under the rational basis test, however. See id. at 539 (O'Connor, J., concurring) (suggesting that preservation of traditional marriage would be a "legitimate" state interest under the rational basis test). Moreover, even leaving marriage equality aside, receiving protection as a "suspect classification" would benefit LGBTs in other areas in which they have faced discrimination, such as adopting children.

242. See id. at 584 (O'Connor, J., concurring) ("In [Romer], we refused to sanction a law that singled out homosexuals 'for disfavored legal status.' The same is true here. The Equal Protection Clause 'neither knows nor tolerates classes among citizens.'" (citing Romer v. Evans, 517 U.S. 620, 623, 633 (1996))).

243. See Varnum v. Brien, 763 N.W.2d 862, 889-92 (Iowa 2009) (stating that the history of discrimination against LGBTs is well-established).

244. See, Recent Case, State Constitutional Law-California Supreme Court Declares Prohibition of Same-Sex Marriages Unconstitutional.-In re Marriage Cases, 183 P.3d 384 (Cal. 2008), 122 Harv. L. Rev. 1557, 1561 (2009); see also Nicole R. Hart, Note, The Progress and Pitfalls of Lawrence v. Texas, 52 Buff. L. Rev. 1417, 1440 n.157 (2004) (noting that courts "seem to rely heavily on immutability"); see also Part II of this Article.

245. Recent Case, State Constitutional Law-California Supreme Court Declares Prohibition of Same-Sex Marriages Unconstitutional.-In re Marriage Cases, 183 P.3d 384 (Cal. 2008), 122 HaRv. L. Rev. 1557, 1558 (2009).

246. Strauss v. Horton, 207 P.3d 48, 59 (Cal. 2009) (noting that the limited question before the court is whether the 2008 amendment to the California constitution was a valid amendment, as opposed to an unlawful revision). 
courts. $^{247}$ Based on the authors' own experiences, we believe that sexual orientation is indeed integral to one's sense of self, and the failure of courts to more forcefully protect vulnerable sexual orientation minorities has led to tragic results.

Ultimately, focusing on immutability leads courts to ask the wrong question, just as asking whether there is a right to "same-sex marriage" or "homosexual sodomy" incorrectly frames the issues. Immutability questions are inextricably intertwined with questions about the origins of homosexuality. In his book, Love Undetectable, Andrew Sullivan notes that the question of from "where homosexuality comes" is at once both fascinating and, in an important sense, irrelevant. ${ }^{248}$ In Sullivan's words, "It seems to me that the only relevant political issue with regard to the nature of homosexuality in a free society is whether it is honestly experienced by adult citizens as involuntary, whatever its genesis." 249 It is this authenticity of experience, a sense of a core part of personhood, that is captured in the notion that sexual orientation is "integral." Also captured within that term is the notion of integrity and the avoidance of any stamp of inferiority, such as that which has too often branded the LGBT community. ${ }^{250}$ Not only in politics, but also in law, this honest sense of self is relevant and deserving of full protection.

"I was thirteen when I first thought I was gay. It was as I sat in my Latin class, thinking about the crushes I was getting on girls, and the exact words that came to me were 'oh, my God, I'm a queer. ...' When Proposition 8 passed, it felt as if I had been thrust back to eighth grade and most of the world hated me."

-Linda J. May ${ }^{251}$

247. See In re Marriage Cases, 183 P.3d 384, 426 (Cal. 2009) (describing sexual orientation as "fundamental" to one's identity), superseded in part by constitutional amendment, CAL. Const. art. I, § 7.5, as recognized in Strauss v. Horton, 207 P.3d 48 (Cal. 2009).

248. Andrew Sullivan, Love Undetectable: Notes on Friendship, Sex, and SuRVIVAL ix (1998).

249. Id.

250. See Lambda Legal, Lambda Legal's Safety Scale: Respect for Same-Sex Couples' Relationships, http://data.lambdalegal.org/publications/downloads/fs_lambda-legals-safetyscale.pdf (last visited Aug. 4, 2009) (noting the inferior treatment of gays and lesbians under the laws of the various states).

251. Appendix of Exhibits in Support of Brief of Amici Curiae Individual Chapman University Organizations, Faculty, Staff, and Students, Orange County Equality Coalition, and Other Orange County Community Members Including Legally Married Same-Sex Couples, in Support of Petitioners at 27-30, Strauss v. Horton, 207 P.3d 48 (Cal. 2009) (No.

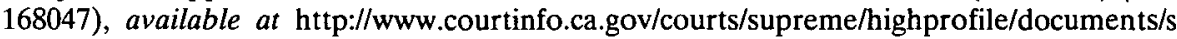
168047-amcur-chapman.pdf (providing the story of Linda May, a single, "out" lesbian). 
"Since the passage of Proposition $8 . \ldots$, the requirement that I 'support and defend' the California [clonstitution 'without any mental reservation' has left me with a crisis of conscience because in fact I have grave reservations about the requirement that I do anything to 'uphold' or 'defend' a part of the [c]onstitution that strips away a fundamental right from a protected minority group."

-Dean Inada ${ }^{252}$

"To insist that a different legal status be substituted for my marriage is to deny something that is so basic to my existence and so integral to who I. am that it would detract from me as a human being and would discard something that is a core element of my life. . . In our own lives and those of friends, we have observed the scars and real damage, measured in human terms and human lives."

\section{- Thomas J. Peterson 253}

"I was depressed and very emotional. ... I both worry for my and my husband's civil rights, and those of our children, given the discrimination that Proposition 8 placed into the Constitution of the State of California." - Jeffrey L. Van Hoosear ${ }^{254}$

\section{Conclusion}

While sexual orientation minorities have won limited victories in the United States Supreme Court, and there has been some progress in expanding federal protections for this class, ${ }^{255}$ the repeal of anti-sodomy laws is not enough. Federal protections remain extremely limited, leaving LGBTs peculiarly vulnerable in the federalist system. ${ }^{256}$ Many states

252. Id. at 21 (providing the story of Dean Inada, an elected member of the Orange County Democratic Central Committee, 70th Assembly District).

253. Id. at 34-36 (providing the story of Thomas J. Peterson, a fifty-two-year-old married gay man).

254. Id. at 39-40.

255. See, e.g., Lawrence v. Texas, 539 U.S. 558, 564 (2003) (invalidating a Texas antisodomy law as an unconstitutional violation of the right to privacy); Romer v. Evans, 517 U.S. 620, 627 (1996) (striking down a Colorado constitutional amendment "withdraw[ing] from homosexuals, but no others, specific legal protection from the injuries caused by discrimination").

256. See Jeremy B. Smith, Note, The Flaws of Rational Basis with Bite: Why the Supreme Court Should Acknowledge Its Application of Heightened Scrutiny to Classifications Based on Sexual Orientation, 73 Fordham L. Rev. 2769, 2794 (2005) (stating that federal courts refuse to consider sexual orientation a suspect class); see also Parts II and IV of this Article. 
provide no real protections to LGBTs, and even those that do may be usurped by the voters. ${ }^{257}$

As if speaking directly to the United States, Spanish Prime Minister José Luis Rodríguez Zapatero said to the members of his parliament before they voted to legalize marriage between same-sex couples on June 30, 2005: "We are not the first but I am sure we will not be the last. After us will come many other countries, driven, ladies and gentleman, by two unstoppable forces: freedom and equality."258 Perhaps the California Supreme Court's landmark 2008 decision can provide a framework for achieving both.

257. See M. Katherine Baird Darmer, "Activist" Courts, Misleading Wedge Politics and the Tragedy of Proposition 8, 14 Nexus 69, 70 (2009) ("It is an unfortunate feature of democracies that the majority can pass laws that disfavor minority groups."); Ronald Steiner, Understanding the Prop 8 Litigation: The Scope of Direct Democracy and Role of Judicial Scrutiny, 14 Nexus 81, 84-85 (2009) (describing many states' initiative systems, allowing the citizens of each state to vote directly on measures to change state constitutions); see also generally Part IV of this Article.

258. Paula L. Ettelbrick, International Gay \& Lesbian Human Rights Commission, Global Warming to Gay Rights: The Worldwide Trend of Recognizing Same-Sex Marriage Will Likely Continue, http://www.iglhrc.org/cgi-bin/iowa/article/pressroom/iglhrcscommentaries/298.html (last visited Aug. 6, 2009). 
